NBER WORKING PAPER SERIES

WHO BLOWS THE WHISTLE ON CORPORATE FRAUD?

\author{
Alexander Dyck \\ Adair Morse \\ Luigi Zingales \\ Working Paper 12882 \\ http://www.nber.org/papers/w12882 \\ NATIONAL BUREAU OF ECONOMIC RESEARCH \\ 1050 Massachusetts Avenue \\ Cambridge, MA 02138 \\ February 2007
}

\begin{abstract}
*Alexander Dyck thanks the Connaught Fund of the University of Toronto and Luigi Zingales the Center For Research on Security Prices, the Stigler Center, and the Initiative on Global Financial Markets at the University of Chicago for financial support. We would like to thank Alexander Phung and Victor Xin for truly outstanding research assistantship. We thank John Donohue, Jay Hartzell, Andrew Metrick, Shiva Rajgopal, Adriano Rampini, and seminar participants at Harvard Business School, Harvard Law School, Michigan Law School, the University of Pennsylvania, the Duke-UNC Corporate Finance Conference, the NBER Summer Institute, the University of Texas Conference on Empirical Legal Studies and the American Finance Association Meetings (2007) for helpful comments. The views expressed herein are those of the author(s) and do not necessarily reflect the views of the National Bureau of Economic Research.
\end{abstract}

(C) 2007 by Alexander Dyck, Adair Morse, and Luigi Zingales. All rights reserved. Short sections of text, not to exceed two paragraphs, may be quoted without explicit permission provided that full credit, including $\odot$ notice, is given to the source. 
Who Blows the Whistle on Corporate Fraud?

Alexander Dyck, Adair Morse, and Luigi Zingales

NBER Working Paper No. 12882

February 2007

JEL No. G3

\begin{abstract}
$\underline{\text { ABSTRACT }}$
What external control mechanisms are most effective in detecting corporate fraud? To address this question we study in depth all reported cases of corporate fraud in companies with more than 750 million dollars in assets between 1996 and 2004. We find that fraud detection does not rely on one single mechanism, but on a wide range of, often improbable, actors. Only $6 \%$ of the frauds are revealed by the SEC and $14 \%$ by the auditors. More important monitors are media (14\%), industry regulators $(16 \%)$, and employees (19\%). Before SOX, only $35 \%$ of the cases were discovered by actors with an explicit mandate. After SOX, the performance of mandated actors improved, but still account for only slightly more than 50\% of the cases. We find that monetary incentives for detection in frauds against the government influence detection without increasing frivolous suits, suggesting gains from extending such incentives to corporate fraud more generally.
\end{abstract}

Alexander Dyck

Joseph L. Rotman School of Management University of Toronto

105 St. George Street

Toronto, Ontario

Canada M5S 3E6

adyck@rotman.utoronto.ca

Adair Morse

University of Michigan

Ross School of Business

701 Tappan Street

Ann Arbor, MI 48109

adairm@umich.edu

\section{Luigi Zingales}

5807 South Woodlawn Avenue

Chicago, IL 60637

and NBER

luigi.zingales@gsb.uchicago.edu 
The large and numerous corporate frauds that emerged in the United States at the onset of the new millennium provoked an immediate legislative response in the Sarbanes Oxley Act (SOX). This law was predicated upon the idea that the existing institutions designed to uncover fraud (e.g., the auditors) had failed, and their incentives as well as their monitoring should be increased. The political imperative to act quickly prevented any empirical analysis to substantiate the law's premises. Which actors play a role in deterring corporate fraud through detection? What motivates them? Did reforms target the right actors and change the situation? Can detection be improved in a more cost effective way?

To answer these questions we gather data on a comprehensive sample of alleged corporate frauds in the United States that took place between 1996 and 2004 in companies with more than 750 million dollars in assets. After screening for frivolous suits, we end up with a sample of 230 cases of alleged corporate frauds, which include all of the high profile cases such as Enron, HealthSouth, and World Com. ${ }^{1}$

Through an extensive reading of each fraud's history, we identify who is involved in the revelation of the fraud, and what are the circumstances that lead to its detection. Using data on the fraud duration we study the timing of revelation to infer which mechanisms are more efficient in revealing fraud. To understand better why these fraud detectors are active, we study the sources of information and the incentives detectors face in bringing the fraud to light. To identify the role played by short sellers, we look for unusual levels of short positions before a fraud emerges.

\footnotetext{
${ }^{1}$ In that follows we will drop the term alleged and simply refer to fraud. While a number of these cases have settled with findings of fact of fraud, the majority of them settled for financial payment without any admittance of wrongdoing and hence, from a legal point of view, remains allegations.
} 
We find that no specific actor dominates the revelation of fraud. Even using the most comprehensive and generous interpretation, shortsellers and equity holders revealed the fraud in only 9 percent of the cases. Financial analysts and auditors do a little better (each accounting for 14 percent of the cases), but they hardly dominate the scene. The Securities and Exchange Commission (SEC) accounts for only 6 percent of detected frauds by external actors. More surprising is the key role played by actors who lack a direct role in investment markets, such as the the media (14 percent), non-financialmarket regulators (16 percent), and employees (19 percent).

As interesting as who detects corporate fraud are who did not. Stock exchange regulators, commercial banks, and underwriters are notable for their complete absence. Also, private security litigation plays a minimal role (less than 2 percent) in the detection of fraud. This does not mean that it is useless to prevent fraud, since it could be the mechanism through which people committing fraud are forced to pay for their mistakes. But it does suggest that this mechanism cannot work alone. It needs another (vast) set of institutions to help bring fraud to light.

Another way to measure the relative efficiency of those actors, besides the frequency, is to look at the average speed with which these actors bring fraud to light. Financial analysts and short sellers are in a league of their own, taking only a median duration of 9.1 months to reveal fraud. These are the players whose market role is closest to a financial monitoring mechanism. Frauds that make it through these monitors are then caught by those with a significant stake in the firm: external equity holders (15.9 months), suppliers, clients and competitors (13.3 months). Non financial market regulators and auditors also seem to intervene at a similar speed (respectively 13.3 and 
14.7 months). Finally, for frauds that persist longer, revelation of the fraud is left to actors with weaker access to the firm, namely, the media (21.0 months), the SEC (21.2 months), and professional service firms like plaintiff lawyers (31.4 months), or to employee whistleblowers (20.9 months).

Having identified the whistle blowers, we then investigate the cost-benefit trade offs they face. Despite their acitivity, analysts, journalists, auditing firms, and employees who bring fraud to light do not seem to be rewarded in monetary or in career terms. Direct payment is made extremely unlikely by insider trading laws that constrain individuals with material inside information from profiting directly by shorting the stock themselves. Thus, we search for other indications of rewards. If detection were a high payoff activity, we would expect those revealing frauds to be the young aggressive types looking to use revealing fraud to promote their careers. By contrast, we find that 59 percent of analysts' detections are done by more seasoned analysts working at top 10 investment banks. In newspapers, almost all the fraud revelations are published in top newspapers by established journalists.

We do, on the other hand, identify real costs to blowing the whistle. Conditional on a fraud being committed, auditing firms are more likely to lose the job when they reveal it than when they do not. In $45 \%$ of the cases, the employee blowing the whistle does not identify him or herself individually and in $82 \%$ of cases with named employees, the individual alleges that they were fired, quit under duress, or had significantly altered responsibilities as a result of bringing the fraud to light.

Generalizing from these results on the identity and incentives of fraud detectors, we arrive at what might be called a paradox of whistle blowing: those with the weakest 
incentives to blow the whistle (e.g. employees) are most active, while those with the strongest incentives to act (e.g. shortsellers) are surprisingly less frequent actors. This paradox can be understood if we espouse Hayek's (1945) view that information is diffuse. Actors with weak incentives have an advantage in whistle blowing because they have superior access to information about the fraud. So, despite having weak incentives, actors with access to information eventually bring frauds to light. In contrast, those with incentives apparently have difficulty accessing credible information to act upon.

In fact, our data reveal the relative merits of two fundamental approaches to fraud detection. The first, which we label the "mandatory" approach, relies on entrusting some individuals with the task of collecting information that might lead to the detection of fraud. This category includes auditors, the SEC, and also possibly non-financial-market regulators. These actors are generally paid for the effort they exert, not for the outcome they achieve. The alternative approach, which we label the "market" approach, does not designate ex ante the people in charge of detecting fraud. By contrast, it provides a reward system for people who bring fraud to light. These incentives can be monetary, as in the case of shortsellers, or reputational, as in the case for the financial analyst who exposes a problem in her report. Overall, mandatory approaches to fraud detection account for only $35 \%$ of our sample, whereas market based institutions account for a much bigger portion, $65 \%$, of our sample.

This overall performance, however, obscures a dramatic change after 2002. While prior to July 2002 , the market-based approach accounted for $73 \%$ of detections, the proportion declined to $46 \%$ of detected frauds after July 2002 . As we explain in section 5, 
this likely is a direct consequence of a series of changes (including the passage of SOX) that focused on increasing the incentives and the penalties for the mandated actors.

Since a Hayekian view of the challenge of fraud detection seems to fit our data best, particularly prior to 2002, we also consider an alternative strategy to the US current regulatory focus on mandated actors: sharpen the incentives of those actors who are endowed with information via a direct payment contingent on the revelation of a fraud. Specifically, we examine the impact of the only notable monetary reward for fraud detection in our sample - monetary awards through the Federal Civil False Claims Act, (also know as qui tam statute). In the situation where the fraud involves a false claim against the government, individuals who bring forward information that identifies the fraud and allows the government to successfully pursue a suit against the company are entitled to between 15 and 30 percent of the money recovered by the government. Consistent with this monetary incentive impacting behavior, we find that in healthcare(an industry where the government accounts for a significant percentage of revenue and thus such suits are more likely) $46.7 \%$ of frauds are brought to light by employees. This contrasts with only $16.3 \%$ of cases detected by employees in all other industries. This difference is statistically significant at the $1 \%$ level. Hence, a strong monetary incentive to blow the whistle does motivate people with information to come forward.

One possible concern with such incentives is that they might be too strong and lead to an excessive amount of frivolous suits. In the healthcare industry, however, we do not find any evidence of that, since the percentage of frivolous suits (suits dismissed or settled for less than 3 million) is lower, not higher, in that industry. 
By contrast, the non monetary incentives for employee whistleblowers introduced by SOX do not lead to an increased rate of detection by employees. In fact, in our sample employee whistleblowing drops from $20.7 \%$ to $15.6 \%$ of cases after SOX.

Our work is related to a large literature in accounting and finance that looks at the characteristics of firms involved in fraud (e.g. Richardson, Tuna and Wu (2002), Burns and Kedia (2006), Efendi, Srivastava and Swanson (2006)), the impact of fraudulent financial reporting on firm value (e.g. Palmrose and Schotz (2004)) and the role of specific whistleblower types including the press (Miller (2006)) and employee whistleblowers (Bowen, Call and Rajgopal (2007)). We differ in our focus: comparing the relative importance of difference sources of detection. We also differ in the broadness of our sample that includes both accounting related and non-accounting related frauds.

Our work is also related to a significant literature in law and economics. As Choi (2004), Griffin, Grundfest and Perino (2001), and Thompson and Sale (2003)), we use federal securities class actions to construct the sample of fraud. The focus of these papers, however, is on the frequency and the cost imposed by fraud, not on the alternative mechanisms of detection. In this respect, our work is closer to Black (2001) and Coffee (2001), who discuss the best mechanisms to protect investors from fraud and raise questions whether specific actors are best thought of as reputation intermediaries who take an active role in policing the system or more simply as transaction engineers who attend to the concerns of their clients. Our paper provides data that sheds light on these questions.

Finally, our analysis reveals mechanisms that bring fraud to light that are not part of the standard analysis of corporate governance, which has typically emphasized the role 
of boards (e.g., Hermalin and Weisbach (1998)) and the presence of large shareholders (Morck, Shleifer and Vishny (1988)). Since corporate fraud can be seen as the ultimate form of mismanagement, in this sense, our paper is related to a large literature on the real effect of bad corporate governance (Becht et al, (2003), and Morck, Wolfenzon and Yeung (2005) provide summaries of this literature).

The remainder of the paper proceeds as follows. Section 1 explains the data and sample selection process. Section 2 analyzes the mechanisms that contribute to fraud detection and their relative efficiency in terms of time it takes them to bring a fraud to light. Section 3 analyzes the costs and benefits of whistle-blowing faced by market-based actors. Section 4 explores the changes in environment occurred after 2002 and their effects on the relative frequency of different whistleblowers. Section 5 summarizes the lesson we can draw from our analysis, while section 6 concludes.

\section{Data}

\subsection{Sample of Frauds}

The ideal sample for evaluating fraud detection would include all firms where the company and/or its officers engaged in fraud. Of course, any sample of observed frauds has the bias of excluding frauds never caught and excluding those caught and corrected privately, a point we discuss in the next subsection. Given that we are working in the realm of observed frauds, we base the construction of our sample on the assumption that all cases of value-impacting fraud lead to a security class action lawsuit filed under the federal 1933 Exchange Act and or the 1934 Securities Act . If this is true, then we can employ the Stanford Securities Class Action Clearinghouse (SSCAC) data, which is the 
most comprehensive database of such suits. This assumption seems to hold for the following reasons.

First, class action law firms have automated the mechanism of filing class action suits so that they start searching for a cause to file a suit every time there is a negative shock to share prices. Since stock prices drop following revelation of most serious corporate frauds, it is highly unlikely that a corporate fraud would emerge without a subsequent class action suit being filed (Coffee, 1986).

Second, the class action suit will most likely be filed under the federal securities laws rather than State laws (Thompson and Sale, 2003). ${ }^{2}$ The federal statute is more stringent than most State laws in that for federal class action is sufficient to provide evidence of misrepresentation (Supreme Court ruling in Green vs. Santa Fe).Thompson and Thomas (2003), who study state class actions suits, show that there are very few state cases (outside of change of control lawsuits) that lead to financial settlement, and many of these also involve a federal class action suit.

The biggest potential problem with using class action data is not that we might miss important frauds, but rather that such an approach might be overinclusive (i.e., containing some allegations that are frivolous). To address this concern we introduce six filters. First, we restrict our attention to alleged frauds that ended in the period of 1996 2004, specifically excluding the period prior to passage of the Private Securities Litigation Reform Act of 1995 (PSLRA) that was motivated by a desire to reduce frivolous suits and among other things, made discovery rights contingent on evidence. During 1996-2004, there are 2171 class action suits.

\footnotetext{
${ }^{2}$ This trend was reinforced by the passage of the Securities Litigation Uniform Standards Act of 1998.
} 
Second, we restrict our attention to large U.S. publicly-traded firms. Large domestic firms have sufficient assets and insurance to motivate law firms to initiate lawsuits and do not carry the complications of cross-border jurisdictional concerns. Operationally, we restrict our attention to firms with at least $\$ 750$ million in assets in the year prior to the end of the class period (as firms may reduce dramatically in size surrounding the revelation of fraud). The size and domestic filters reduce our sample to 501 cases.

Third, we exclude all cases where the judicial review process leads to their dismissal. ${ }^{3}$ Fourth, for those class actions that have settled, we only include those firms where the settlement is at least $\$ 3$ million, a level of payment previous studies suggested to divide frivolous suits from meritorious ones. ${ }^{4} \mathrm{We}$ also explore the robustness of our findings to higher cutoff point for settlement: $\$ 10$ million and $\$ 50$ million.

Fifth, we exclude from our analysis those security frauds that Stanford classifies as non standard, including mutual funds, analyst, and IPO allocation. ${ }^{5}$ The third through fifth screens more than halve the number of cases from 501 to 244 cases.

The final filter removes a handful of firms that settle for amounts of $\$ 3$ million or greater, but where the fraud, upon our reading, seems to have settled to avoid the negative publicity. The rule we apply is to remove cases in which the firm's poor ex post

\footnotetext{
${ }^{3}$ We do retain cases voluntarily dismissed when the reason for dropping the suit is bankruptcy for in this instance the cases could still have had merit but as a result of the bankruptcy status, plaintiff lawyers no longer have a strong incentive to pursue them.

${ }^{4}$ Grundfest (1995), Choi (2004) and Choi, Nelson, and Pritchard (2005) suggest a dollar value for settlement as an indicator of whether a suit is frivolous or has merit. Grundfest establishes a regularity that suits which settle below a $\$ 2.5-\$ 1.5$ million threshold are on average frivolous. The range on average reflects the cost to the law firm for its effort in filing. A firm settling for less than $\$ 1.5$ million is most almost certainly just paying lawyers fees to avoid negative court exposure. To be sure, we employ $\$ 3$ million as our cutoff.

${ }^{5}$ Stanford Class Action Database distinguishes these suits for the reason that all have in common that the host firm did not engage in wrongdoing. IPO allocation cases focus on distribution of shares by underwriters. Mutual fund cases focus on timing and late trading by funds, not by the firm in question. Analyst cases focus on false provision of favorable coverage.
} 
realization could not have been known to the firm at the time when the firm or its executives issued a positive outlook statement for which they are later sued. ${ }^{6}$ This filter removes 14 cases producing our final sample of 230 cases.

While we use the term fraud, strictly speaking these are only examples of alleged frauds. Settlements almost always involve no admittance of wrongdoing. As a result, it is impossible for us to establish whether there was real fraud (which in legal terms implies the intent to deceive) or just gross negligence. For the purpose of this paper, however, this difference is not so relevant. We are interested in understanding the mechanisms that bring extreme bad forms of governance to light, not in establishing intent. For simplicity, in the rest of the paper we do not use the adjective "alleged". The appendix relates this sample to other samples of fraud used in the literature.

\subsection{Sample Selection Biases}

By focusing on discovered frauds, we introduce two biases. First, we do not observe frauds that were committed but were never caught. The intense public scrutiny of large U.S. firms, the ability to go back in time and sue based on past wrongdoing, and the strong incentives to sue by plaintiff lawyers, likely diminish this problem, but it still is a possibility.

Second, we do not observe frauds caught so early that they never enter the public domain; hence, we cannot say anything about the importance of specific mechanisms in preventing fraud that does not occur. This is a more serious limitation for considering

\footnotetext{
${ }^{6}$ An illustrative example of such dropped cases is Carnival Corporation. After its stock price plunged $41 \%$ in a month following a period with significant fires and mechanical problems on a number of its cruise ships, Carnival Corporation was sued. The fraud allegation was that the company did not comply with applicable safety regulations and minimized the extent of such safety problems in its public statements. The relatively low settlement amount ( $\$ 3.4$ million) combined with the fact that the company had strong motive to settle regardless of the merits of the case (the company's profitability depended upon its public reputation), led us to drop this case.
} 
fraud detection by internal control mechanisms. For example, monitoring by the board of directors either directly or through the audit committee might be very effective in deterring fraud and in stopping frauds early on. As a result of missing such early fraud detections, our data do not allow us to measure the effectiveness of such internal governance mechanisms. What our data do allow us to evaluate are which are the most effective external mechanisms that help detect corporate fraud when there is a failure of internal mechanisms. This is a limited but important aspect of governance that has received little attention.

\subsection{Identifying the Detector of Fraud}

The key variable we focus on is the identity of the actor who brings the fraud to light. To do this, we manually collect information on events surrounding the fraud and its detection from news reports, the SSCAC database, and other public sources for each of our 230 cases. Our primary source of data is Factiva, where we search the comprehensive database of news and wire reports over the range beginning three months prior to the class period and going until the settlement date or until current if the case is yet pending. The only limit we apply to our search is to require that the firm's name is in the first 30 words of the article. We do not restrict the media source from which the article might be drawn because we are concerned that local newspapers may conduct more thorough investigative reporting of local firms. Thus, we sacrifice having to read more articles rather than miss such important fact-finding. Our searches return an approximate average of 800 articles per case, reflecting in part the newsworthiness of the alleged frauds and of the companies in question (related to their size). ${ }^{7}$

\footnotetext{
${ }^{7}$ To address potential concerns about subjectivity in identifying the first actor to bring the fraud to light, we used the following procedure. To ensure consistent coding, the initial classification of the fraud detector
} 
In many cases the news reporting about the fraud clearly indicates what actor brought this particular fraud to light, for example, a particular analyst, or employee, or government regulator. In other cases, the evidence is more indirect such as the simultaneous reporting of an auditor being fired and a discussion of difference of opinion regarding what come to be characterized as fraudulent reporting at the firm. Our ability to access reports following the initial uncovering of the fraud and that emerged in additional legal and regulatory scrutiny of the cases often revealed actors behind the scene that forced the firm to come forward with the information (e.g. employees). In all cases, we try to identify the actor that identified the concern if this lead to the fraud coming to light. This means in the case of the media that we only attribute the media as the identifier of the fraud if the media story does not give credit for the information to any specific source, named or unnamed (e.g. anonymous employee).

In a number of cases we find that the whistleblower is not the person labeled by the media as such. A chain of events initiated by another entity may already be forcing the scandal to light when an individual expedites the process by disclosing internal information. For instance, Enron's whistleblower by our classification is the Texas edition of the Wall Street Journal, not Sherron Watkins who is called the Enron whistleblower in the media. Of course, we do not want to discredit the importance of internal individuals identified as participating in bringing fraudulent activity to the public. However, our aim is to identify the initial force that starts the snowball of a scandal coming to light. In the Enron example, investigative reporting by the Texas version of

was done by a single research assistant who was involved in all cases. Each case was also examined by a minimum of one author of the paper. Where significant judgment was required, a file was prepared of relevant information, all three authors read the file and agreed on the coding the outcome, often requiring additional searches to satisfy ourselves of the classification. 
the Wall Street Journal raises concern about Enron's marking-to-market practices and the source of firm revenues a full 8 months prior to employee whistle blowing.

\subsection{Fraud Duration}

A second variable we focus upon is the duration of the fraud. The securities class action filing identifies a class period, giving a begin date and end date for the fraud. Because this period can and often is revised as the suit progresses, we use the most recent definition. The passage of SOX produced a change in the statute of limitations for filing cases from three years to five years. The legal requirement may have influenced the reported duration of the fraud in the class action particularly prior to $2002{ }^{8}$ To address this issue we have reclassified the maximum duration through our whole sample period to be three years (1,095 days).

\subsection{Other Variables}

In the analysis that follows, we will at times reexamine the distribution of fraud detectors controlling for characteristics of the fraud and industry. We will describe the variables when introduced. Table 1 provides definitions of all variables and sources

\section{An Analysis of the Fraud Detection Process}

\subsection{Who Detects Corporate Fraud?}

Table 2 presents the initial distribution of fraud detectors for the cases in our sample. We begin by noting that even after reading through the large number of articles on companies before and after the fraud comes to light we still attribute $32 \%$ of the fraud

\footnotetext{
${ }^{8} \mathrm{We}$ examined this issue by comparing the fraud duration data and the length of financial restatements for all the firms in our sample with both sources of data. We find that, in part as a result of the statute of limitations on class actions, class periods are conservative estimates of frauds, with restatement periods on average being 223 days longer than class periods
} 
detections to the firm itself. We do not draw specific conclusions about the effectiveness of internal control systems based on this evidence alone as we do not observe those potential frauds also caught (and stopped) by these parties. ${ }^{9}$ One approach that would allow such inferences would be to compare differences in board characteristics of firms in our sample and in non-fraud companies, as done by Bowen, Call and Rajgopal (2007) for firms with employee whistleblowers. This is a very valuable endeavour, but a different one from what we are pursuing here: the role played by external monitors. For this reason, in what follows we will focus on the $68 \%$ of frauds caught by external mechanisms.

As Table 2 shows, the SEC accounts for $6 \%$. percent. Financial analysts and auditors do a little better (respectively 15 and 14 percent of the cases), but they hardly dominate the scene. Shortsellers, who should have the strongest incentive to uncover fraud, account for only 1 percent. Even more surprising is the key role played by actors who lack a governance mandate, such as the employees (19 percent), the media (15 percent), and industry regulators (15 percent).

\subsection{Importance of Shortsellers in Fraud Detection?}

A potential concern with these results is that some actors have an incentive to avoid being seen as the source of the information and that we may be misattributing responsibility for these actors, in particular the short sellers. Shortsellers have a strong incentive to identify bad news and disseminate it (Diamond and Verrachia (1987)) but no incentive to reveal themselves as the source. A fraud-revealing short seller might be

\footnotetext{
${ }^{9}$ What we can say, based on findings in Dyck, Morse and Zingales (2007), is that these revelations generally follow a negative operations shock ( $27 \%$ of these cases) or restructuring and managerial turnover ( $23 \%$ of the cases), consistent with insiders being pushed to reveal the information. And we do not find that these cases are masking specific external pressures as very rarely is revelation the result of outside scrutiny ( $4 \%$ of the cases).
} 
cutoff from future information from firms and might face suits or investigations for spreading false information (e.g. Lamont (2003)). As a result, the fact that we only attribute fraud detection to short sellers in 2 cases out of 230 may be because we have not identified their work behind the scenes.

We investigate the possibility that shortsellers might be more active by identifying whether the level of short interest in a stock helps to predict the timing of the fraud coming to light, controlling for other factors. We construct a monthly short interest variable with data from Bloomberg, where we normalize short interest by the number of the shares outstanding from CRSP to make the data comparable across companies. Our goal is to answer whether short interest positions prior to fraud can predict detection among all possible monthly dates 1994-2004.

Table 3 provides evidence consistent with shortsellers predicting fraud and possibly having a role in its detection. The most straightforward test is to estimate a logistic regression of whether fraud is detected in that period as a function of lagged short interest and aggregate short interest (as a percentage of market shares). The aggregate shares variable controls for possible changes in short activity driven by non-firm specific factors. Column 1 reports that short selling is a positive and significant predictor of fraud detection in our sample.

Columns 2-4 back this finding up by introducing additional controls and examining if short-sellers are more likely to work in combination with a particular type of actor. Column 2 includes additional controls for the type of fraud - whether the fraud involves accounting restatements and the type of fraud committed (self-dealing, misrepresentations on financial statements, failure to disclose, or other non-financial 
illegal activity). Column 3 is even more stringent, replacing these controls with firm fixed effects. Finally, in column 4, we run separate regressions for each fraud detector type, again with controls that are allowed to vary by fraud type.

These regressions indicate a symbiotic relationship between shortsellers and a range of actors. There is a significant association between abnormal shorting and detection by buyers, suppliers, and competitors (columns 2-4), media (columns 2, 4), analysts (column 4), and auditors (column 2). These results are consistent with other research that suggests shortsellers are informed as they target firms with accounting restatements and high accruals, anticipated downward analyst revisions, and negative earnings surprises (e.g. Desai et. al (2005)).

While Table 3 indicates shortseller activity is associated with detection, it does not provide any indications about which specific cases should be reclassified as shortseller related. To explore this possibility we conducted a related test, whereby we look at individual time series of short positions and ask whether the lagged short position could predict fraud detection for each company. Since a test for significance of a single point event is fraught with noise, we ask whether the 6 month average pre-detection short interest is greater than the mean short interest position (excluding a year and a half around the fraud) plus 2 standard deviations. The criterion is fairly stringent, as two standard deviations increase the short position $60 \%$ on average.

In Figure 1 we plot the evolution of short interest around the date of the end of the class period for those with short interest greater than or equal to 2 standard deviations, one standard deviation, one half standard deviation and the median firm in our sample. The group with more than two standard deviation difference in short interest includes 16 
cases, eight of which we reclassify as shortseller cases. The reclassified cases were previously the media ( 4 cases), analysts ( 2 cases), an auditor ( 1 case) and a client (1 case). As a quality check, we re-analyzed each of these cases to search for explanations of the sources of the information in the fraud detection to see it there were reasons to eliminate a role for short sellers, and found no such cases. We do not reclassify the remaining eight cases because in two of them, the employee is the fraud detector and there is little reason that communication went from shortseller to employee. In the other six cases, the timing indicates that the shortselling activity began after the detector we have identified brought the fraud to attention.

\subsection{Who Acts to Detect Frauds, Accounting for Indications of Shortseller Activity?}

In Table 4, we now reexamine who detects corporate fraud after having reclassified the additional 8 cases where there are indications of shortseller involvement. In all remaining tables in the paper we use this reclassified data.

The data suggests one clear picture: no specific actor dominates the revelation of fraud. The United States apparently relies upon a village of fraud detectors, many lacking a governance mandate.

A second fact emerging from Table 4 is the relative unimportance of many mechanisms emphasized in the literature. Completely missing are investment banks, commercial banks and stock exchanges. The absence of these actors in fraud detection is consistent with Coffee's (2001) hypothesis that these actors had "neither the obligation nor the right to make disclosure when any reasonable doubt exists concerning the client's obligation of disclosure", Coffee (2003). This result does not preclude the possibility that 
these actors played a more indirect role: not accepting jobs from companies whenever a concern of fraud emerged.

Even private security litigation, emphasized by legal scholars such as Coffee (1986), plays a minimal role in the revelation of fraud: less than 2 percent of the cases. This does not mean that private litigation is useless in preventing fraud, since it could be the mechanism through which people committing fraud are forced to pay for their mistakes. But it does suggest that this mechanism cannot work alone.

Similarly, the SEC accounts for only $6 \%$ of the cases, the auditors for $14 \%$, the financial analysts for another $14 \%$. Even the short-sellers are very marginal $(6 \%$ of the cases). More important are the media, which only recently have been considered as an important player in corporate governance (Zingales (2000), Dyck and Zingales (2004), Miller (2006), Dyck, Volchkova, and Zingales, (2006)). Even more important are players generally neglected by the corporate governance literature such as the employees (19\%) and non-financial-market regulators $(16 \%)$.

\subsection{How Fast Do They Act?}

The relative frequency of detection is not the only measure. Of great importance is also the speed of detection, i.e. how long it takes between the beginning of the fraud (defined as the beginning of the class action period) and detection. The faster that frauds are brought to light, the quicker the market can respond to this information. Table 4 reports these speeds of detection, expressed in months since the beginning of the fraud.

Financial analysts and short sellers are in a league of their own, taking only a median duration of 9.1 months to reveal fraud. Frauds that make it through these monitors are then caught by auditors (14.7 months) and non-financial market regulators 
(13.3 months). At a similar speed, however, operates also a heterogeneous group of actors: external equity holders (15.9 months), and suppliers, clients and competitors of the firm (13.3 months).

Finally, for frauds that persist longer, revelation of the fraud is left to actors with weaker access to the firm, namely, the media (21.0 months) and professional service firms like plaintiff lawyers (31.4 months), to employee whistleblowers (20.9 months), or to the SEC (21.2 months). While this evidence on the speed of various actors could be influenced by characteristics of the fraud, column 6 shows that this is unlikely to be the case, as the rank order of median durations after accounting for various characteristics is practically unaltered.

\subsection{Is There Specialization by Different Fraud Detectors?}

It is possible that certain actors specialize in detecting fraud of certain characteristics (type of misconduct, whether the fraud requires restatements, and whether the industry is regulated). If so, the frequency across all frauds may underestimate an actor's role if that actor is a specialist.

Table 5 splits the data by various criteria. Panel A breaks down frauds by four types of fraud introduced in Dyck, Morse and Zingales (2006): whether the fraud involved self-dealing, whether the fraud involved other potentially illegal activity, and for the frauds that do not fit into these categories, whether the alleged fraud primarily focused upon financial misrepresentations (about the past or the future) or failure to disclose material information (about the past or the future).

Our main results seem robust: it takes a web of monitors to detect fraud, and we continue to see the importance of actors who lack a governance mandate. There are also 
indications of limited specialization. We, not surprisingly, find that auditors and analysts do better in failure-to-disclose cases. But even in this category, media and employees play a significant role. Analysts (but not auditors) are also effective in misrepresentation cases, but employees and non financial market regulators account for almost twice as many detections in this category. Media, non-financial market regulators and employees account for the lions share of activity in policing self dealing and other illegal activity, while analysts are completely absent and the SEC plays no role in revealing self-dealing cases.

Panel B and Panel C explore splits on whether the fraud required financial restatements ${ }^{10}$ (and hence may be a particular area of concern for auditors and financial market regulators) and whether the firm was in a regulated industry or not (and hence open to scrutiny by financial market regulators). Again, our main results are robust, while revealing some degree of specialization. In Panel B, auditors clearly specialize in restatement related frauds while analysts specialize in non restatement frauds. Panel C shows how non financial market regulators specialize in regulated firms, a group where they account for almost one quarter of detections, the single greatest frequency. Among non-regulated firms, short sellers are twice as frequent detectors as for regulated firms.

Panel D examines whether the distribution of fraud detectors differs as we change the magnitude of the settlement amount used as a cutoff for frivolous suits. Column 1 reports the distribution of whistleblower for all the cases that either did not settle or settled for more than $\$ 3$ million. Column 2 reports the distribution only for cases that settled for more than $\$ 3$ million, while columns 3 and 4 for cases that settled for more

\footnotetext{
${ }^{10}$ Many frauds require financial restatements but others do not, normally as a result of a "failure to disclose" material information, and/or a disclosure of misleading forward-looking information. The Data Appendix provides further information on the construction of this variable.
} 
than $\$ 10$ and $\$ 50$ million. The chi-square test in panel $\mathrm{D}$ reveals that the distributions are not significantly different suggesting little bias in focusing on the results using the complete sample. Interestingly, shortsellers and the media are more important in the cases with the largest settlement amount while both the SEC and the auditors are less important. Since larger cases are generally associated with larger companies this might reflect the stronger influence that large firms have both on the regulators and on the auditors. Overall, this evidence confirms the need for a web of monitors against fraud.

\section{6 $\quad$ Adjusted Duration Analysis}

In Figure 2 we present yet one more approach to characterizing our findings on frequency and duration. The graph plots the results of a competing risk model (a variant of hazard rate analysis), viewing each of our fraud detectors as competing sources for detecting fraud, and controlling in a regression format for the nature of the fraud and for whether financials were restated. Specifically, we estimate a Cox proportional hazard model assuming that the likelihood of detection depends upon the fraud detector, and upon the same characteristics of the fraud that we used in the adjustments to median duration described above. The plot indicates for each date of duration of the fraud ( $\mathrm{x}$ axis) what is the probability of detection (y axis) for a given fraud detector, given a fraud has not yet been detected and given the characteristics of the fraud. Thus, for example both at the $25^{\text {th }}$ percentile duration and at the median duration of fraud in our sample (indicated by dashed vertical lines), the analyst line is highest indicating that analysts are the most important actors for frauds of these durations.

This figure reinforces our previous findings (based on duration data) that analysts are, with shortsellers, the first to act. In addition, it shows that analysts are also the most 
frequent actors at these durations. The fact that they are not the most dominant actors overall comes from the fact that they are almost entirely absent for frauds of longer than median duration (as it is reflected in the flat slope of the line after the median).

Similar analyses can be done for each other actor. The relatively flat slope for the auditor line up to approximately 365 days indicates that it takes a year for auditors to act. The steep slope between 365 and 730 days indicates that auditors are active in the range between one and two years after the beginning of the fraud. They become inactive again after two years.

The relatively constant slope of the media and non financial market regulators lines suggests that these detectors are involved at all durations, including short ones. The lower slope of the professional service and financial market regulator lines with a pickup later on indicates their almost exclusive relevance for frauds of longer duration.

The employee line is particularly interesting. They are involved in detection at all durations, but they become more important at fraud of longer duration as indicated by the increasing slope of the line. The height of the line at the end indicates their absolute importance for frauds of the longest duration.

\subsection{Interactions Among Detectors of Fraud}

Attributing all the credit to one single whistleblower per case misses all the interactions between different sources of information. In the Enron case, for instance, the early article in the Texas edition of The Wall Street Journal attracted the interest of a hedge-fund manager, who began to scrutinize the company's financial statements and assembled a short position. The hedge-fund manager, in turn, tipped off a reporter at Fortune, Bethany McLean, who in March, published a story entitled "Is Enron 
Overpriced?", where she questioned how exactly Enron made its money. Another shortseller tipped off Peter Eavis, of TheStreet.com, who in an article on May 9, 2001 started to mention shady "related entities". Even Smith and Emshwiller (the Wall Street Journal reporters generally credited for the discovery of Enron's fraud) benefited from "sources close to Enron < who> began to furnish the Journal with documents" (Sherman 2002).

As this example shows, without such interactions, it may be that the initial suggestions of fraud may not be widely disseminated and/or believed. Illustrating this potential problem is HealthSouth where the fraud would likely have been detected and stopped earlier if the concerns of former bookkeeper Michael Vines were heeded when he left the company in May 2002. As emerged after the fact in response to Congressional concerns about how this fraud could have gone detected for so long, Vines reportedly sent his concerns to Ernst and Young, but was ignored, and then in early 2003 posted his concerns on Yahoo web site, where he wrote: "I know for a fact that HRC has assets on the books that are made up to trick the auditors." This information channel lacked credibility, as suggested in the comments of an online naysayer: "If you really had information, you would have shorted the stock and given your info to the appropriate people. You wouldn't be babbling about it here."11

Table 6 provides indications of some of these interactions. This table reports "to whom" the whistle was blown, identifying the next actor after the fraud detector involved in bringing the fraud to light. For shortsellers and analysts, for example, the media is clearly a complementary actor being the "to whom" actor in $60 \%$ and $57 \%$ of cases respectively. Analysts also enjoy their own credibility, being the "to whom" actor for

\footnotetext{
${ }^{11}$ By Carrick Mollenkamp, Wall Street Journal, May 20, 2003," Missed Signal: Accountant Tried In Vain to Expose HealthSouth Fraud --- Ex-Employee Took His Case To Auditors, Then Web -- But Convinced No One --- What About the Others?
} 
$20 \%$ of the shortseller cases. At the same time, in $38 \%$ of the cases the analysts are the end of the line, and blow the whistle directly to the "public".

Employees rely upon a wider range of additional actors including non-financial regulators (33\%), lawyers $(13 \%)$, the SEC $(10 \%)$, the media (3\%), and other external (3\%). In $37 \%$ of these cases, employees whistle blowing is followed up by the firm revealing the information. The overall takeaway is that looking at interactions reinforces our earlier findings of the importance of a range of actors, and particularly reinforces the relevance of the media and non-financial regulators who account for $23 \%$ and $10 \%$ of cases in the "to whom" channel respectively.

\subsection{Where Do the Fraud Detectors Get Their Information?}

Finally, we ask what were the primary sources of information used by each fraud detector in identifying the fraud. For each fraud, we read the case and identified the likely source of the information by the detector. We contrast information that arises from SEC mandated disclosures and information derived from all other sources. Among other information sources we distinguish information that could be constructed from public sources (e.g. comparing a firm relative to competitors); information that emerges from non-financial market regulator requirements; and information internal to the firm.

Table 7 presents these results. Except for the employees, the auditors, and the non financial market regulators, all the actors rely heavily on SEC disclosure. Thus, financial disclosure is crucial for fraud detection (39\% of the cases), but insufficient. To identify fraud it is often necessary to have access to information inside the firm ( $37 \%$ of the cases). In only a third of these cases do the auditors reveal the fraud, in almost half, the employees. The other major source of information is regulatory discovery $(15 \%$ of the 
cases). Only $8 \%$ of the frauds are identified thanks to private collection of information. One third of these investigations are done by analysts.

Given the variety of information sources, these results confirm the need for a web of monitors to detect fraud. They also highlight the costs associated to collecting the information to reveal a fraud. Only $24 \%$ of the fraud detection is the result of information collected in a specific investigation. The vast majority seems serendipitous discoveries by people who had access to the crucial information in the normal course of their business. The crucial question, then, is what are the incentives for these people to reveal the fraud? We will attempt to answer this question in the next section.

\section{What Are the Incentives to Blow the Whistle?}

Some actors- like auditors and financial market regulators — have a clear mandate to bring fraud to light. But what motivates the others? We focus our discussion on those groups where we have a relatively large number of observations - financial analysts, the media, and employees - and on plaintiff law attorneys, an actor prominent in discussions of the importance of private enforcement. To organize our analysis of each of these actors we will focus on four factors that, as theory suggests, should be crucial: the access to information at low cost, the incentives to collect additional information, the monetary or career benefit from whistle blowing and the costs whistle blowers can face. Before doing so, we note that the fraud detectors we observe are those who had the highest incentives to do so and hence our estimate of the cost-benefit ratio is downward biased. This makes the findings that we detail below, that their monetary and career 
incentives to blow the whistle are in almost all circumstances very low, particularly remarkable.

\subsection{Financial Analysts}

We identify a fraud detector as a financial analyst if they work in a brokerage house or investment bank or if they work for investors directly, issuing newsletters or public statements about companies.

From an information point of view, analysts are well located. While they do not have direct access to company information, especially after regulation FD (adopted by the SEC in August of 2000) curtailed their privileged access to companies' management, they are in the business of collecting information for valuation purposes. So while their goal is not to search for fraud, they might be particularly well positioned to identify it, by comparing results across companies in the same industry. Table 7 provides some useful indications of the relative importance of information from these channels, with this collectible public information accounting for $19 \%$ of cases and information internal to the firm accounting for $14 \%$ of cases.

Viewed as agents of professional investors, analysts appear to have strong incentives to reveal fraud. Each analyst is paid to analyze companies and has potentially improved career prospects for establishing a reputation of insightful analysis valuable to investors. Identifying frauds is one part of establishing such a reputation (e.g. Fama (1980), Hong and Kubik (2000)). ${ }^{12}$ Analysts' incentives to reveal fraud, however, may be reduced by the potential conflict of interest between the advising they do and the investment banking services their company generally offer (e.g. Michaely and Womak

\footnotetext{
${ }^{12}$ Consistent with such career concerns in the analyst industry, Hong and Kubik (2000), for example, report that good forecast records are rewarded by upward mobility to higher-tiered brokerage houses, and the maintenance of jobs in top-tier brokerage houses.
} 
(1999)). Their incentives to reveal fraud may also be significantly reduced or eliminated by their tendency to herd. ${ }^{13}$ Finally, before regulation FD analysts might have had incentives to develop a good reputation vis-à-vis the companies they followed to gain privileged access to soft information. If this were the case, they might not have the right incentives to bring a fraud to light.

Our findings lend support to both views. The fact that analysts are the first line of defense in terms of the speed at which they detect fraud suggests their capabilities to detect frauds. But the fact that analysts only account for 15 percent of our observations suggest that this channel has not been fully exploited.

To further our understanding of financial analyst incentives in our sample, we gathered information on the identity of the analyst that brought the information to light, including the investment bank they worked for. To explore the potential impact on their career, we investigated the three year window surrounding the revelation of fraud. Since we do not have access to their bonus information, our only proxy for their career prospect is the Institutional Investor All American Analyst ranking. The magazine gives individuals this designation based upon a survey they conduct each year of buy-side money managers. As Hong and Kubik (2000) report, “All Stars” are actively sought by investment banks and receive the highest salaries.

Consistent with Hong, Kubik, and Solomon (2000), we find in Table 8 that analysts' willingness to go against the herd (as signified by their identifying fraud) increases with age and with the status of their brokerage house: 59 percent of financial

\footnotetext{
${ }^{13}$ Sharfstein and Stein (1990) for example identify a "share the blame" effect whereby costs are greater in being different and incorrect, than in being incorrect like everyone else. This herding based bias is greater when analysts are young and there is uncertainty about their ability.
} 
analyst detections are associated with analysts in top 10 investment banks, 14 percent in brokerage houses ranking $11^{\text {th }}-40^{\text {th }}$, and 27 percent in other institutions.

But we do not find any evidence associated with a significant reward for detecting

fraud. No financial analyst changed into a different investment bank tier in the two years following their revelation of fraud. And there was only a small change in likelihood of being an All Star. Prior to detection, 24 percent of the analysts detecting fraud belonged to the All Stars group. Following the revelation of fraud, the probability of entering the elite group is only an additional 6 percent. Unfortunately, we do not have a good measure of the counterfactual (what this probability would have been had they not identified the fraud), but even if the alternative would have been zero, a 6 percentage point increase does not seem a very high reward.

\subsection{Media}

Journalists are similar to analysts, in the sense that they collect and analyze information for their clients (the readers). They also have an incentive to build a reputation of being nice vis-à-vis companies in order to cultivate their sources (Dyck and Zingales (2003)). And as with analysts, there may also be a conflict arising from the fact that the companies in their stories often make direct payments to their employers (e.g. advertising).

The main difference between journalists and analysts is that journalists are much less specialized than analysts and thus potentially have access to less company and industry specific information. On the upside, however, journalists might benefit more from revelation of fraud, because a scoop may help establish their career and reputation. 
The data in Table 7 show that for cases where media are the whistle blowers, they rely most heavily on mandated disclosure, accounting for $71 \%$ of cases.

Our data seem to suggest that the incentives to reveal fraud differ tremendously between major national outlets and minor ones. As Table 9 shows, 11 of the 13 cases reported by newspapers are published in the Wall Street Journal or the New York Times. Similarly, Business Week and Fortune account for 5 of the 6 cases identified by magazines. Why do minor and local newspapers play no role?

One possibility is that minor newspapers cannot afford the most talented journalists able to do the investigation necessary to discover fraud, cannot afford to pay for the cost of these investigations, or focus such activity on smaller more local companies. ${ }^{14}$ An alternative hypothesis is that only very established media with a diversified advertising base can afford to alienate potential (or actual) advertisers. The pressure faced by Fortune when it was about to publish the first negative report on Enron gives credibility to the second hypothesis. ${ }^{15}$

That most newspapers are not willing to pay and publish scoops on corporate fraud might also reflect the fact that these types of news are less entertaining (Miller (2006), Dyck, Moss, and Zingales (2005)). After all, the National Enquirer pays a fortune to find out every possible detail about the personal lives of media stars.

\footnotetext{
${ }^{14}$ In Miller's (2006) study of firms with SEC Accounting, Auditing and Enforcement Releases which includes many smaller companies, he finds that local news outlets report frauds in 30.7 percent of cases flagged by the press prior to revelation by the firm.

15 As reported in the New York Times, "Her questions were so pointed that Enron's chief executive, Jeffrey K. Skilling, called her unethical for failing to do more research. Three Enron executives flew to New York in an unsuccessful effort to convince her editors that she was wrongheaded. Enron's chairman, Kenneth L. Lay, called Fortune's managing editor, Rik Kirkland, to complain that Fortune was relying on a source who stood to profit if the share price fell." Felicity Barringer, "10 Months Ago, Questions on Enron Came and Went With Little Notice,” 28 January 2002, Page 11, Column 1.
} 
Table 9 also tries to get at the personal career incentives of the journalists. While many of the journalists involved are national figures who also write books, it is not clear that they became national figures by exposing fraud. The upside from revealing information seems limited. On the positive side, however, the downside seems limited as well. While there are many stories insinuating that analysts got fired for their negative report on companies, we are not aware of any claim that journalists get fired for this reason. Hence, journalists might be better protected than analysts on the downside associated with whistle blowing.

\subsection{Employees}

In no case is the tension between access to information and lack of incentives to reveal fraud more intense than for employees. Employees clearly have access to information; few, if any, frauds can be committed without involving some interaction among the people within a firm. However, the career incentives against revealing the fraud are stronger for employees than for any other group. Even according to an advocate for whistleblowing, consequences to being the whistleblower include distancing and retaliation from fellow workers and friends, personal attacks on one's character during the course of a protracted dispute, and the need to change one's career. ${ }^{16}$

To elucidate under what context an employee whistleblower would act, we construct Table 10, a summary of the whistleblower position and incentives for each of the 30 cases for employee whistleblowers. As expected, the burdens of whistleblowing are large. In $82 \%$ of cases where the identity of the whistleblower was revealed, s/he was fired, quit under duress, or had significantly altered responsibilities. In addition, many employee whistleblowers report having to move to another industry and toanother town.

\footnotetext{
${ }^{16}$ See quitam.com.
} 
Referring to James Bingham, a whistleblower in the Xerox case, his lawyer said: "Jim had a great career, but he'll never get a job in Corporate America again."

The surprising part, thus, is not that most employees do not talk; it is that some talk at all. Table 10 tries to give a sense of what motivates them. In $45 \%$ of the cases, the costs of blowing the whistle are eliminated by keeping the identity of the whistleblower concealed. ${ }^{17}$ This is often the case when the company is unionized. The unions seem to be in a good position to protect the whistleblowing employee from the potential retaliation.

In 35 percent of the cases ( 6 out of 17) where the identity of the whistleblowers is known, we observe a qui tam lawsuit. Such suits arise from the Federal Civil False Claims Act, revised in 1986, whereby individuals revealing fraud committed against the U.S. government can collect $15-30 \%$ of the money recovered by the government. In our sample, two qui tam cases that have already settled rendered whistleblowers with rewards of $\$ 35$ million and $\$ 70$ million. More generally, the outcome of qui tam suits is very uncertain and very delayed in time ( 5 and 10 years in these cases), but the expectation is that these rewards might have been an important factor in leading the employee to talk.

In addition to the monetary reward in the form of qui tam payments, the revelation of information seems to be associated to a wrongful dismissal claim in another $30 \%$ of the cases ( 5 out of 17$)$. These are cases in which the employee has already been fired, and so s/he has less to lose. In the remaining $35 \%$ of the cases, however, it is

\footnotetext{
${ }^{17}$ This includes 9 cases where the individual is anonymous, 3 cases where there multiple individuals all associated with an employee organization blowing the whistle, and 2 cases where a change of authority from one to another accounting group (e.g. arising from a merger) brought out the information and the group rather than any individual is associated with the information.
} 
difficult to find a rational reason for the employee to talk, especially in light of the very high emotional costs paid by whistleblowers.

\subsection{Plaintiff Law Firms}

In the corporate governance literature private enforcement plays a prominent role among the set of mechanisms to protect shareholders (e.g., La Porta et al., 2003). In our sample we find only two cases (equal to 1.4 percent) where a security class action is the mechanism that triggers the revelation of fraud. In both cases, the class action suit leads to the discovery of information about managerial self dealing. For example, in the case of Sprint, the plaintiff sues the company for the failed merger with WorldCom and this leads to the discovery of a bylaw, introduced by management just before the attempted merger, ensuing them a payoff regardless of the outcome of the merger.

That class action plays almost no role in the revelation of fraud does not mean it is not an important mechanism to prevent fraud. First of all, it could play an important role in punishing who has committed fraud. Second, it could help publicize and make credible the claims made by other whistle blowers. At the very minimum, however, our finding suggests that private litigation alone is not sufficient to stop fraud. It can only work when a web of other mechanisms help bring fraud to light.

\subsection{How Much Do Incentives Matter?}

As a test of the effect of incentives on whistle-blowing, we exploit the fact that qui tam lawsuits are not available in all industries, but only in very few industries where the government is a significant buyer of services. Specifically, in Table 11 we compare the distribution of whistleblowers between the healthcare industry, which is a significant buyer of government services, and all other industries. Consistent with this incentive 
having a significant impact, we find a striking difference, with employees accounting for $46.7 \%$ of cases of fraud detection cases in the healthcare industry vs. $16.3 \%$ in industries where employees cannot easily avail themselves of the rewards from qui tam lawsuits. Since a Chi-Square test rejects the hypothesis that the distributions are equivalent, we can conclude that these types of incentives matter. ${ }^{18}$

A potential objection against stronger incentives to whistle blowing is that these incentives might create a free option for the employees, leading to an excessive amount of false claims. ${ }^{19}$ To test this proposition we look at the frequency of frivolous suits (suits dismissed or settled for less than 3 million) in the healthcare industry (where these incentives are present) and in the other industries (where they are not clearly present). We find that the percentage of frivolous suits (panel B) is lower in the healthcare industry. Hence, there is no evidence that stronger incentives to blow the whistle lead to more frivolous suits.

\section{Did the Situation Change After the Major Scandals?}

Thus far we have considered the whole period 1996 to 2004 as homogenous. But after the turn of the millenium many things have changed. First, in 2000 regulation Fair Disclosure was approved, making it impossible for analysts to have private conversations with top executives of the firms they follow. According to the proponents of this measure, this change should have increased analysts' independence, making them more

\footnotetext{
${ }^{18}$ This also provides a rationale for Bowen, Call and Rajgopal's (2007) finding that employee whistleblowing were more likely in firms in 'sensitive' industries, which they defined as including pharmaceuticals, healthcare, medicine, the environment, oil, utilities and banksl .

${ }^{19}$ Bowen, Call and Rajgopal (2007) provide a more extended discussion of this issue and related literature.
} 
likely to reveal fraud. According to the opponents, this change could reduce analysts' incentives to search for information, making them less likely to reveal fraud.

In late 2001 and early 2002 the Enron Scandal and the collapse of Arthur Andersen increased the risk faced by auditors and thus their incentives to speak up.

In July 2002 the Sarbanes Oxely act was passed, introducing a vast array of changes. SOX made SEC involvement more politically appealing by providing that SEC civil penalties be used to compensate investors that were victims of securities fraud. It also made SEC involvement more feasible by significantly increasing its budget. SOX also dramatically changed auditors incentives by introducing a ban on consulting work done by audit firms, by making it clearer that their primary responsibility was to the board, and through section 404 requiring enhanced internal controls and investigation of control weaknesses by auditors.

SOX also altered the cost of whistleblowing for the employees. Section 301 requires audit committees of publicly traded companies to establish procedures for "the confidential anonymous submission by employees of the issuer of concerns regarding questionable accounting or auditing matters." It also enhances protections for employees against being fired for coming forward with such information.

Finally, in April 2003 the New York Attorney General reached a settlement with ten of the nation's top investment firms aimed at promoting the independence of equity research. If this Global Research Settlement achieved its goal, the analysts should have become more independent and thus active in revealing fraud.

Since all of these changes took place almost simultaneously, it is impossible to separate the effect of each one of them. It is possible, however, to see whether the relative 
frequency of the different type of whistleblowers changed according to the net changes in their relative incentives.

Table 12 examines changes in the activity of auditors before and after Enron. It reveals a significant uptick in the overall level of auditor involvement in detection and in the scope of their detection activity. Prior to Enron, auditors accounted for just $9.6 \%$ of frauds detected by external actors, and focused exclusively on frauds requiring financial restatements. Post Enron, they account for $16.9 \%$ of cases, and their activity is spread across not only financial restatement cases, but also those cases not involving restatements. One possible explanation for this broader scope is auditors' increased exposure to liability for a firm's fraudulent activity. Another is that auditors become more aware of fraudulent activity as a result of their responsibility in evaluating internal controls per SOX section 404.

In Table 13 we examine time trends more comprehensively, looking at changes pre and post SOX for the overall distribution of fraud detectors. The table shows a stunning increase in the role of auditors (a four fold increase in the relative frequency of detections) and of the SEC (a doubling of their importance, albeit from a very low level). The increased role of the auditors come at the expense of analysts (who drop from 14 to $11 \%$ of the cases of detection), of shortellers (from 9 to $0 \%$ ), and the media (from 15 to $9 \%)$.

That the percentage of employee whistleblowers (Table 13) drops from 21 to 16\% suggests Sox's modest incentives for whistleblowers have not been very effective. One possible explanation is that protecting the whistleblower current job is a small reward given the extensive ostracism whistleblowers face. Another explanation could be that 
many firms either go bankrupt or are bought up after revelation of fraud. As a result, job protection in the pre-existing firm is but a small reward.

\section{The Paradox of Whistle Blowing}

Generalizing from our results, we arrive at what might be called a paradox of whistle blowing: those with weakest incentives to blow the whistle (e.g. employees) are most active, while those with the strongest incentives to act (e.g. shortsellers) act very rarely. This paradox can be understood in the context of Hayek's (1945) idea that information is diffuse. The whistleblowers with weak incentives have superior access to information about the frauds and this access to information eventually leads to its use despite the weak incentives. Those with incentives, by contrast, have difficulty accessing credible information to act upon.

This Hayekian view suggests a distinction between two approaches to fraud detection. The first, which we might label the "mandated" approach, consists of entrusting some individuals with the task of collecting information that might lead to the detection of fraud. These individuals are generally paid for the effort they exert, not for the outcome they achieve. These actors include external auditors, financial market regulators, industry regulators, and other non-financial market government offices.

The alternative approach, which we might label the "market" approach, does not designate ex ante the people in charge of detecting fraud. By contrast, it provides a reward system for people who bring fraud to light. These incentives can be monetary, as in the case of shortsellers, reputational, as in the case of financial analysts exposing problems in their reports, or moral, as is alleged with some employee whistle blowing. 
In comparing the functioning of these two systems, which coexist as in the U.S. market, it is useful to focus on two dimensions: the cost to collect the information necessary to identify fraud and the incentives not only to collect this information, but also to reveal it. At one extreme, we have shortsellers, who can benefit handsomely from the revelation of bad news, but have the most limited access to company-specific information and thus are likely to have the highest cost to collect it. On the other hand, we have employees. They have the lowest cost of collecting information: they stumble on frauds in the regular course of their jobs. But they generally derive no benefit from revealing bad information. In fact, they often pay a significant cost in doing so in terms of loss of employment, ostracism, verbal and sometimes even physical harassment. Between these two extremes lay all the other actors.

The two approaches differ in the way they use incentives and in the way they tap into the diffuse information already present in the system. With diffuse information, the market works best when incentives are provided where the information is. The mandated system, in contrast, designates those with responsibility and requires that information be provided where the incentives are (or at least where there are no strong disincentives).

As Table 4 makes it clear, the market approach dominates fraud detection during this period. The mandated approach accounts for just $20 \%$ of detections if we restrict our focus to auditors (14\%) and the financial market regulators (6\%). If we adopt a more encompassing view of mandated mechanisms and also count non-financial-market regulators, this total only increases to $36 \%$ of our sample. In contrast, all market based actors collectively account for $64 \%$ of cases. 
It is possible that mandated actors could, in part, make up for their relative infrequency of action by being much quicker to act, which would improve affairs as efficiency is clearly enhanced if information about the frauds was brought to the attention of the public earlier. But we find that this is not the case. As shown in column 5, the median duration of frauds caught by market actors is 15 months, marginally faster than frauds caught by mandated actors as a whole (15.8 months) and definitely faster than frauds caught by financial market mandated actors (16.8 months).

This dominance of market-based actors was much more extreme pre 2002, when market-based actors accounted for $73 \%$ of the cases detected. After 2002 , mandated actors were more active with a $56 \%$ to $44 \%$ lead. This change is mainly due to a surge in the activity of auditors. One explanation for these results is that the mandate was poorly designed prior to 2002 and these mandates have been strengthened. External auditors historically have been tasked with attesting that the financial information provided by firm management is prepared consistent with generally accepted accounting principles and while required to report fraud that they see, they have not had an obligation to seek out fraud. ${ }^{20}$ The nature of this mandate has changed only recently. In 1997 a Statement of Auditing Standard clarified that auditors had a responsibility to detect material misstatements. More importantly, the passage of SOX increased the obligation of auditors in this domain. .

\footnotetext{
${ }^{20}$ This distinction can be traced as far back as the Kingston Cotton Mills Case of 1896, which concluded that auditors were not responsible for uncovering frauds "It is the duty of an auditor to bring to bear on the work he has to perform that skill, care, and caution which a reasonably competent, careful, and cautious auditor would use. An auditor is not bound to be a detective, or, as was said, to approach his work with suspicion, or with a foregone conclusion that there is something wrong. He is a watchdog, but not a bloodhound. Auditors must not be made liable for not tracking out ingenious and carefully laid schemes of fraud, when there is nothing to arouse their suspicion ...So to hold would make the position of an auditor intolerable." Lord Lopes, 1896, cited in Sarup (2004).
} 
Similarly, while the SEC has responsibility in policing against fraud, it has suffered from a paucity of resources, particularly during the late 1990s and has since then seen an increase in its budget. ${ }^{21}$

What this study cannot determine is which aspect of the post 2002 reforms has triggered a change in auditors' behavior. Is it the severing of the consulting business with their clients, the effect of the demise of Arthur Andersen, the effect of required increased professional skepticism by auditors, or the increased awareness of frauds arising from implementation of section 404 and internal controls? In other words, is this a permanent change or a temporary reaction to an event that made the risk of bad auditing salient, reaction that will subside with time? Only time will tell.

What our study can determine, however, are the effects of the other reforms. And overall, they seem to be ineffective. Analysts do not seem to be more active as a result of regulation FD and the global research settlement. Similarly, employees do not appear to feel protected by the provisions in section 301 of SOX.

What our study can also suggest is a different approach to reforms. As the evidence in the healthcare industry shows, employees respond to incentives and a reward to whistle-blowing leads to a higher rate of detection. This higher rate of detection does not appear to come at the cost of more frivolous suits.

The idea of extending the qui tam statue to corporate frauds (i.e. providing a financial award to those who bring forward information about a corporate fraud) is very

\footnotetext{
${ }^{21}$ As the GAO (2002b) reports, "The percent of all corporate filings that received a full review, a full financial review, or were just monitored for specific disclosure items decreased from about 21 percent in 1991 when 13,198 were reviewed to about 8 percent in 2000 when 8,498 were reviewed" Further analysis is provided in Mark Maremont and Deborah Solomon, "Missed Chances: Behind SEC's Failings: Caution, Tight Budget, '90s Exuberance --- Its Reactive Culture Made Agency Slow Off the Mark While Spitzer Raced Ahead --- Giving Up Too Soon on Tyco,"Wall Street Journal, 24 December 2003.
} 
much in the Hayekian spirit of sharpening the incentives of those who are endowed with information. This proposal has an additional benefit. If it does not work and no whistleblower provides useful information, no money will be spent for the reward. In this regard, it is a much more cost-effective than usual forms of regulation, where the cost is borne even if the regulation has no positive effect. And if the reward system works very well and is very effective in deterring corporate fraud, very little money will be paid in rewards because very little fraud will be committed. Once again, this is different from a mandated approach, where the costs have to be paid even when the deterrence effect makes frauds extremely unlikely.

\section{Conclusions}

The clearest result emerging from our data is that in the United States fraud detection relies on a wide range of, often improbable, actors. No single one of them accounts for more than $20 \%$ of the cases detected. These findings suggest that the failures of internal governance in other countries cannot be easily solved by introducing U.S. institutions like class action suits or the SEC (together they account for only $8.4 \%$ of the revelation of frauds by external actors). An effective corporate governance system relies on a complex web of market actors that complement each other. Unfortunately, reproducing such a complex system abroad is much more difficult than copying a single legal institution.

The other clear result is that, at least before SOX, the "mandated" approach to fraud detection did not work well at all. Only $5.8 \%$ of the fraud cases were identified by the authority in charge of discovering them (i.e., the SEC). Even if we enlarge the definition and we include external auditors (who have a duty to disclose fraud when they 
find it, but not to search for it) and industry regulators (who are not in charge to look for financial frauds), only $35.3 \%$ of the cases were revealed by people appointed to search for it.

One interpretation of these results is that information about fraud is so diffuse that is extremely costly (and so ineffective) to appoint an official investigator: it is like looking for a needle in the proverbial haystack. Fraud tends to be revealed by people who find out about it in their normal course of business and who do not have any strong disincentive (or even better have some positive incentive) to reveal it. For example, in sectors like healthcare where qui tam suits are possible and thus whistleblowers are rewarded, employees play a much bigger role in revealing fraud.

Unfortunately, we have shown that in many real world situations (like auditors, analysts, and employees in other sectors) there are little or no monetary or career-related incentives to reveal fraud. That only the most established newspapers and the most senior analysts are willing to come forward suggests - to the contrary- that the risks involved in blowing the whistle are substantial.

After the introduction of SOX, which significantly increased their duties and monitoring, the performance of mandated actors improved. Still they account for only slightly more than $50 \%$ of the cases. Only time will tell whether this recent surge in their relative performance is just a temporary blip, due to the enormous amount of public scrutiny that certain actors (like auditors) received after a few major corporate scandals, or a permanent shift due to the changes in the incentives imposed by legislation. 
Either way our analysis suggests an alternative, cheap, way to address the problem: to extend the qui tam legislation to corporate fraud. As the evidence in the healthcare industry shows, such a system seems to work very effectively.

An objection to this approach is that it might lead to an excessive amount of frivolous suits. But the evidence in the healthcare industry seems to dismiss this concern. Another objection is that an explicit reward to whistleblowers might foster distrust among employees, undermining their ability to work together for the benefit of the company. We are not aware of any sign of this problem in sectors subject to qui tam suits, but this is certainly an aspect that deserves further study before this idea is implemented. 


\section{Data Appendix}

\section{Comparing Our Sample with Other Fraud Samples}

Many accounting studies focus on a sample of companies identified by the GAO that restated their financial statements between 1997 and June 2002 (e.g. Palmrose and Scholz (2004)). This 'GAO sample' includes all type of restatements (i.e. major and minor, revenue increasing and decreasing, and as a result of new GAAP, reclassification of accounts, merger/acquisition, restructuring charges or fraud).

Our sample differs in two principle ways. First, many of these cases will not make it into our sample. This arises because the GAO sample includes: some non-US firms; the GAO sample includes many smaller firms that do not meet the selection criteria for our sample (the median market cap in the GAO sample (measured at date t-1) is \$ 214 million while the market cap of firms in our sample (also measured at t-1) is \$ 3525 million); and, because the underlying fraud is not sufficiently serious to trigger a lawsuit that withstands scrutiny and yields a settlement or is ongoing. Second, this approach does not allow for cases of fraud where firms do not issue restatements, a category of frauds that accounts for 38 percent of our observations.

Other accounting studies have focused on a narrower sample of firms where the SEC has sanctioned the firm and released an Accounting, Auditing and Enforcement Release (AAER) (e.g. Dechow, Sloan and Sweeney (1996), Miller (2006)). We will capture these cases if there is a simultaneous suit under federal securities laws that meets our tests for inclusion. The SEC sample also is focused on smaller firms (the median market cap (measured at t-1) for AAER firms is 262 million) and, given its limited budget, on a few high profile and egregious cases of fraud. ${ }^{22}$ Our companion paper provides a more complete comparison of these samples and the relationship of our sample to these.

The larger size of firms in our sample likely corresponds with additional scrutiny both before the fraud was brought to light and evaluation of the fraud and how it got uncovered after the fact. This additional scrutiny aids us in identifying the likely source of the information about fraud and in identifying some of the interactions among fraud detectors, including identifying actors who pushed the board to action. These factors help to account for the higher percentage of cases in our sample where indications of fraud arise from actors outside the firm. In our sample, we identify the firm as the source of information in $32 \%$ of cases whereas the firm is identified as the source in between $49 \%$ and $58 \%$ of cases in the GAO sample (1997-2002, and 2002-2005 respectively), and in $71 \%$ of cases in the AAER sample used by Miller (2006). ${ }^{23}$

\footnotetext{
${ }^{22}$ Dechow, Sloan and Sweeney (1996) write: "because our sample is subject to SEC enforcement actions, it is almost certainly biased toward the inclusion of the more obvious and spectacular cases of earnings manipulation."

${ }^{23}$ Correspondence with Shiva Rajgopal, January 2007.
} 
Legal scholars have been the biggest user of the SSCAC database to construct samples of probable frauds (see citations above). A potential concern with this sample is that it is potentially missing additional cases of alleged fraud that are filed as a class action under state laws or as a derivative action. Thompson and Sale (2003) and Thompson and Thomas $(2003,2004)$ provide analysis and evidence that exploring such suits would not turn up many additional cases as there has been a profound shift in cases from state to federal courts, accentuated by the passage of PSLRA and the Uniform Standards Act (1998). Their comprehensive analysis of these filings in Delaware in 1999 and 2000 shows that almost all such cases that withstand scrutiny are breach of fiduciary duties in merger and acquisitions (and thus not fraud in the general use of this term in that they do not involve misrepresentations).

\section{Identifying Frauds that Require Restatements}

We distinguish between frauds that required financial restatements and frauds that do not. To identify whether the fraud involved restatements we used information from the United States General Accounting Office (GAO) report on Financial Statement Restatements that identifies 918 restatement announcements from 1997 to June 2002, which we matched to those in our sample. We also searched a firm's SEC filings after the revelation of fraud for either (a) a 10-Q/A or 10-K/A filing which indicate amended filings; or (b) an 8-K which referred to restatement information. We identified a fraud as involving misrepresentation if any of the following conditions applied: it restated its financials [116 cases]; it announced an intention to restate its financials but did not as a result of bankruptcy (e.g. Enron) [7 cases]; it took a one-time accounting-related charge [ 6 cases]; and, it is an ongoing case where there are accounting-related investigations [3 cases].

The residual category of frauds that don't require financial misrepresentation, are primarily composed of "failure to disclose" material information, and a disclosure of misleading forward-looking information, with the case of CVS illustrating the first type and Ascend the second type. In the case of CVS, the alleged fraud was to issue positive statements concerning its business and operations and possibilities for expansion but not to disclose that a national shortage of pharmacists was negatively impacting CVS's business forcing a scale back in expansion plans. Or consider the case of Ascend Communications, where the company followed a competitor's announcement that it would ship a $56 \mathrm{~K}$ modem, with a near immediate announcement that it too would ship a $56 \mathrm{~K}$ modem and beat the competitor to market, even though there were strong indications, including the supplier that allegedly would produce the modem, that suggested this was not possible. 


\section{References}

Bar-Gill and Lucien Bebchuk, 2003, "Misreporting Corporate Performance," John M Olin Center for Law, Economics and Business, Harvard Law School Working Paper Series.

Black, Bernard, 2001, “The Legal and Institutional Preconditions for Strong Securities Markets," UCLA Law Review, Vol 48 (1), 781-855.

Bowen, Robert, Andrew Call and Shiva Rajgopal, "Whistle-Blowing: Target Firm Characteristics and Economic Consequences," 2007, working paper, University of Washington.

Burns, N. and S. Kedia. 2006. The impact of performance-based compensation on misreporting. Journal of Financial Economics 79: 35-67.

Coffee, John, 1986. “Understanding the Plaintiff's Attorney,"Columbia Law Review, 669727.

Coffee, John, 2001, “The Acquiescent Gatekeeper: Reputational Intermediaries, Auditor Independence and the Governance of Accounting," Columbia Law and economics Working Paper No 191.

Coffee, John, 2003, "The Attorney as Gatekeeper: An Agenda for the SEC."

Choi, Stephen J. 2004, "Do the Merits Matter Less after the Private Securities Litigation Reform Act?" Working Paper.

Choi, Stephen J. 2005, "Behavioral Economics and the SEC.” Working Paper.

Choi, Stephen J., Karen K. Nelson and A.C. Pritchard. 2005. "The Screening Effect of the Securities Litigation Reform Act.” Working Paper.

Cox, James D., Randall S. Thomas and Diku Kiku. 2003. "SEC Enforcement Heuristics: An Empirical Inquiry." Duke Law Journal, 53(2), pp. 737-79.

Dechow, P. M., R. G. Sloan, and A. Sweeney. 1996. "Causes and consequences of earnings manipulation: An analysis of firms subject to enforcement actions by the SEC." Contemporary Accounting Research, 13 (1): 1-36.

Desai, Hemang, Srini Krishnamurthy and Kumar Venkataraman, 2006, "Do short sellers target firms with poor earnings quality?: Evidence from earnings restatements," Reveiw of Accounting Studies, March.

Diamond, D., Verrecchia, R., 1987. "Constraints on short-selling and asset price adjustment to private information”. Journal of Financial Economics 18, 277-311. 
Efendi, Jap, Anup Srivastava, and Edward Swanson, forthcoming, "Why Do Corporate Managers Misstate Financial Statements? The Role of in-the-money Options and Other Incentives," Journal of Financial Economics.

Dyck, Alexander and Luigi Zingales, 2003,"Media and Asset Prices," working paper

Dyck, Alexander and Luigi Zingales, 2004, "Private Benefits of Control: An International Comparison", Journal of Finance 59: 537 - 600.

Dyck, Alexander, David Moss, and Luigi Zingales, 2005, "Media vs. Special Interests", working paper.

Dyck, Alexander, Adair Morse and Luigi Zingales, 2006, "The Nature of Corporate Fraud," working paper.

Dyck, Alexander, Nathalia Volchkova, and Luigi Zingales, 2006, "The Corporate Governance Role of the Media: Evidence from Russia" NBER Working Paper.

Fama, Eugene, 1983. "Agency Problems and the Theory of the Firm," Journal of Political Economy, 88 (2): 288-307.

General Accounting Office, 2002, "Financial Statement Restatements: Trends, Market Impacts, Regulatory Responses, and Remaining Challenges," 03-018

General Accounting Office, 2002b, "SEC Operations: Increased Workload Creates Challenges," 02-302.

Griffin, Paula, Joseph Grundfest and Micael Perino, "Stock Price Response to News of Securities Fraud Litigation: Market Efficiency and the Slow Diffusion of Costly Information," Stanford Law and Economics Olin Working Paper No. 208.

Grundfest, Joseph A. 1995. “Why Disimply?” Harvard Law Review, 108, 740-741.

Hayek, Friedrich, 1945, "The Use of Knowledge in Society," American Economic Review, 34 (4), 519-530.

Healy, Paul and Krishna Palepu, 2003,"The Fall of Enron," Journal of Economic Perspectives, Spring.

Hermalin, Benjamin E. and Michael S. Weisbach (1998) "Endogenously Chosen Boards of Directors and Their Monitoring of the CEO," American Economic Review, 88: 98116. 
Hong, Harrison, Jeffrey D. Kubik and Amit Solomon (2000) "Security Analysts' Career Concerns and the Herding of Earnings Forecasts," Rand Journal of Economics 31, 121-144.

Hong, Harrison, and Jeffrey D. Kubik (2000) "Analyzing the Analysts: Career Concerns and Biased Earnings Forecasts," Journal of Finance, vol. 58, no. 1, February 2003, pp. 313-51

Johnson, Marilyn F., Ron Kasznik, and Karen K. Nelson. 2000. "Shareholder Wealth Effects of the Private Securities Litigation Reform Act of 1995." Review of Accounting Studies, 5(3) 217-233.

Johnson, Marilyn F., Karen K. Nelson and A.C. Pritchard. 2003. "Do the Merits Matter More? Class Actions under the Private Securities Litigation Reform Act." Working Paper.

Lamont, Owen, 2003, "Go Down Fighting: Short Sellers Versus Firms," working paper.

La Porta, Rafael, Florencio Lopez-de-Silanes, Andrei Shleifer, 2006, "What Works in Securities Laws," Journal of Finance, 61, 1-33.

Michaely, Roni and Kent L. Womack (1999) "Conflict of Interest and the Credibility of Underwriter Analyst Recommendations," Review of Financial Studies 12, 653686.

Miller, Gregory S. 2006, "The Press as a Watchdog for Accounting Fraud." Journal of Accounting Research 44, no. 5 (December): 1001-1033.

Morck, Randall, Andrei Shleifer, and Robert Vishny (1988) “"Management Ownership and Market Valuation: An Empirical Analysis", Journal of Financial Economics 20: 293-316.

Morck, Randall, Daniel Wolfenzon, and Bernard Yeung (2005) "Corporate Governance, Economic Entrenchment, and Growth" Journal of Economic Literature, XLIII: 655720.

Palmrose, Z-V., and S. W. Scholz. 2004. The circumstances and legal consequences of non-GAAP reporting: Evidence from restatements. Contemporary Accounting Research. 21 (1) (Spring): 139-180.

Richardson, Scott, Irem Tuna and Min Wu, 2002, "Predicting Earnings Management: The Case of Earnings Restatements,"

Sarup, Deepak, 2004, "Watchdog or Bloodhound? The Push and Pull Toward a New Audit Model," Information Systems Control Journal,, Volume 1. 
Thompson, Robert and Hillary Sale, 2003, "Securities Fraud as Corporate Governance: Reflections Upon Federalism," Vanderbilt Law Review

Thompson, Robert and Randall Thomas, 2004,"The Public and Private Faces of Derivative Lawsuits," Vanderbilt Law Review.

Winston, Clifford, 1998, "U.S. Industry Adjustment to Economic Deregulation," Journal of Economic Perspectives," 89-110.

Zingales , Luigi, 2000, “In Search of New Foundations,” Journal of Finance, 55: 16231653. 


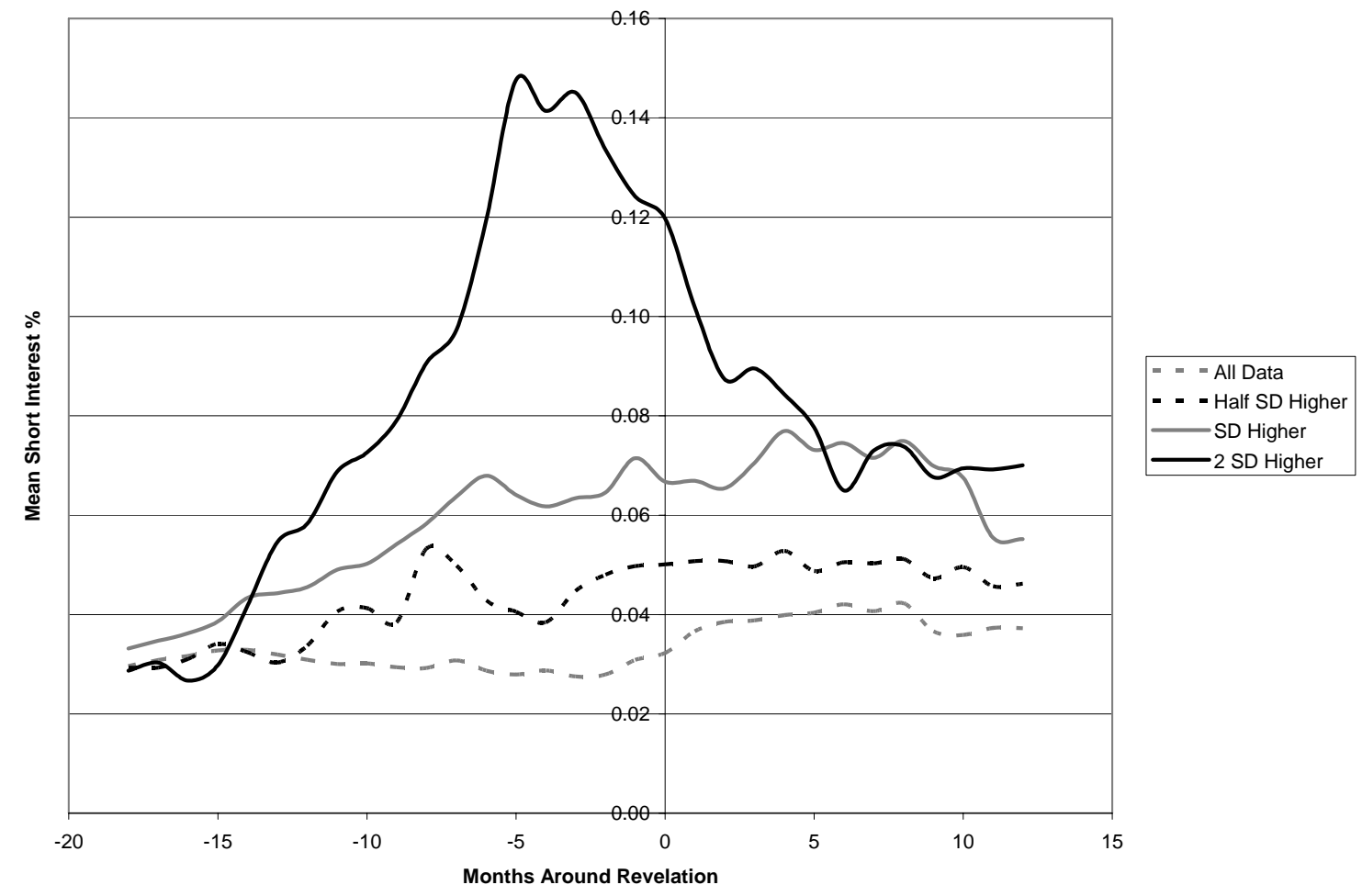

\section{Figure 1 - Short Interest and the Timing of Fraud Detection}

This figure illustrates the pattern of short interest around the timing of fraud detection in our sample. Short interest is defined as the total number of shares investors have sold short but have not yet bought back. divided by the total number of outstanding shares for each company. The standard deviation bands are defined based on the 6 month average pre-detection short interest relative to the mean short interest position for that firm (excluding a year and a half around the fraud). 


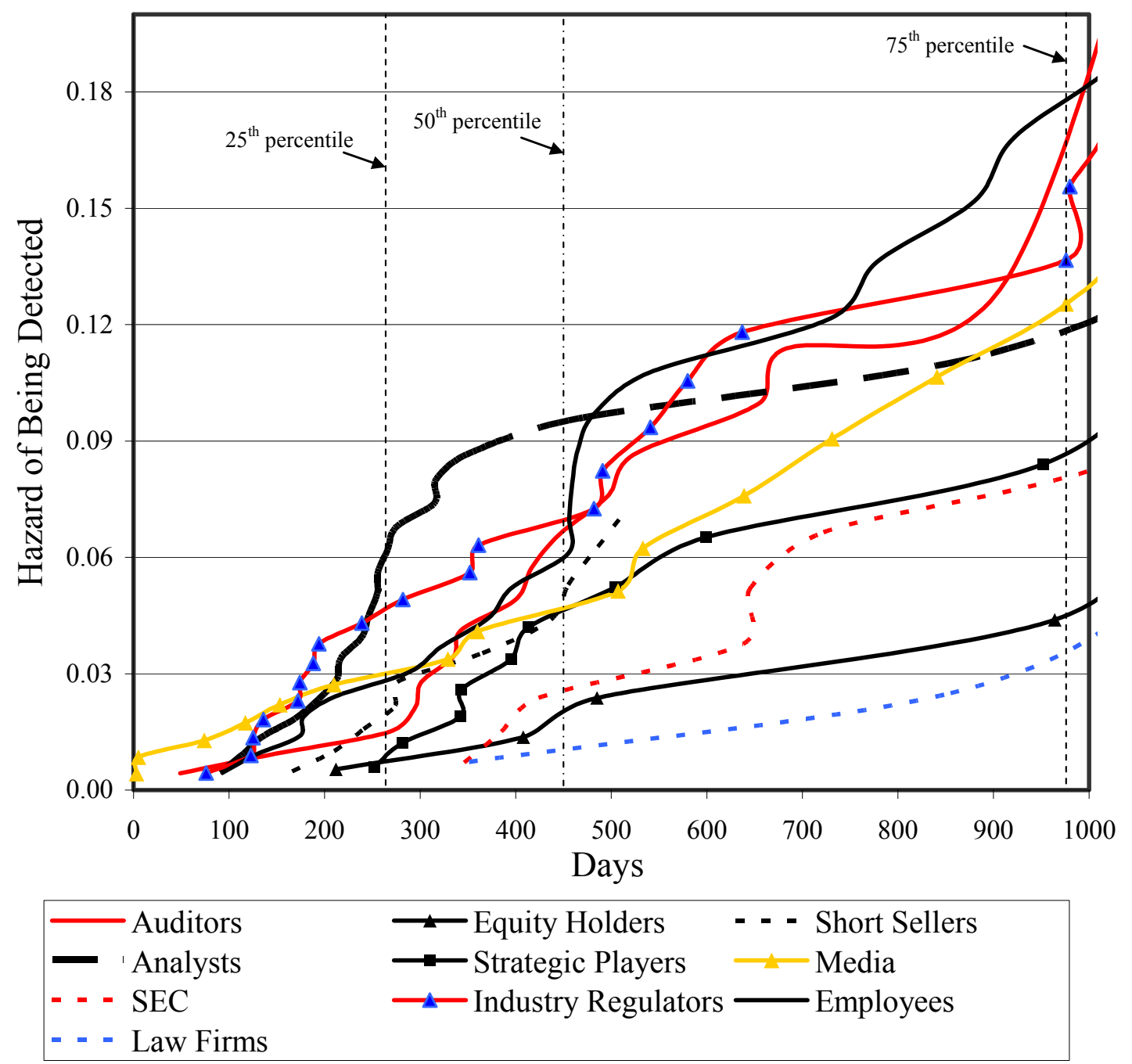

\section{Figure 2 - Hazard of Being Detected by Fraud Detector}

This figure is based on a Cox proportional hazard model of the likelihood of detection. For each duration the figure plots the probability of detection by each fraud detector (i.e. 1- survival probability), after controlling for the type of fraud. A higher line at a specific duration indicates that type of fraud detector is more likely to have detected the fraud up until that point. 
Table 1 - Data Definition and Sources

This table identifies the main variables used in our analysis, defines the variables, and provides the sources.

\begin{tabular}{|c|c|c|}
\hline Variable & Description & Sources \\
\hline $\begin{array}{l}\text { Detector of } \\
\text { Fraud }\end{array}$ & $\begin{array}{l}\text { The actor who first identifies the fraud based on a combined reading of the legal case documents and an average of } 800 \\
\text { articles from Factiva in a window from } 3 \text { months before the class action period to settlement. Ten detector categories } \\
\text { include: external auditor, financial analyst, investor, shortseller, media, strategic players, financial market regulators, } \\
\text { non-financial market regulators, employees and professional service organizations. The detection is attributed to the } \\
\text { media only when the story does not indicate another actor as the principal source of information. Strategic players } \\
\text { include suppliers, clients and competitors. Financial market regulators are the SEC and stock exchanges. Non-financial } \\
\text { market regulators include industry regulators (e.g. FERC, FAA, FDA) and other government agencies. Professional } \\
\text { service firms are law and insurance firms. }\end{array}$ & $\begin{array}{l}\text { Security Class actions filings } \\
\text { available from Stanford Securities } \\
\text { Class Action Database, Articles in } \\
\text { Factiva. }\end{array}$ \\
\hline Fraud Duration & $\begin{array}{l}\text { The class period defined in the security class action, reflecting all adjustments made before settlement. We restrict the } \\
\text { maximum duration to } 3 \text { years, to avoid changes in duration possibly arising from changing rules with the passage of } \\
\text { Sarbanes-Oxley in July of } 2002 \text {. }\end{array}$ & $\begin{array}{l}\text { Stanford Securities Class Action } \\
\text { Database }\end{array}$ \\
\hline $\begin{array}{l}\text { Financial } \\
\text { Restatement } \\
\text { Dummy }\end{array}$ & $\begin{array}{l}\text { Observation has value } 1 \text { if: the firm filed a } 10-\mathrm{Q} / \mathrm{A} \text { or } 10-\mathrm{K} / \mathrm{A} \text { filing or an } 8-\mathrm{K} \text { which referred to restatement information } \\
{[116 \text { cases]; it announced an intention to restate its financials but did not as a result of bankruptcy (e.g. Enron) [7 cases]; }} \\
\text { it took a one-time accounting-related charge [ } 6 \text { cases]; and, it is an ongoing case where there are accounting-related } \\
\text { investigations [ } 3 \text { cases]. }\end{array}$ & $\begin{array}{l}\text { SEC filings, General Accounting } \\
\text { Office (GAO) report on Financial } \\
\text { Statement Restatements. }\end{array}$ \\
\hline $\begin{array}{l}\text { Regulated Firm } \\
\text { Dummy }\end{array}$ & $\begin{array}{l}\text { Firm in following categories: financials (SIC 6000-6999), transportation equipment (SIC 3700-3799), transportation, } \\
\text { communications, electric, gas and sanitary services (SIC 4000-4999), drug, drug proprietaries and druggists sundries } \\
\text { (SIC 5122), petroleum and petroleum products wholesalers (SIC 5172), pharmaceuticals (SIC 2830-2836), and } \\
\text { healthcare providers (8000-8099), and healthcare related firms in Business Services. }\end{array}$ & $\begin{array}{l}\text { Industries identified in Winston } \\
\text { (1998) and others. }\end{array}$ \\
\hline $\begin{array}{l}\text { Nature of Fraud } \\
\text { Controls }\end{array}$ & $\begin{array}{l}\text { Dummy variables identify primary nature of fraud as either self-dealing, non-accounting related illegal activity (e.g. } \\
\text { price fixing and non-compliance), financial misrepresentations, and failure to disclose. }\end{array}$ & $\begin{array}{l}\text { Dyck, Morse and Zingales (2006) } \\
\text { based on Factiva and Security Class } \\
\text { actions filings. }\end{array}$ \\
\hline Short Interest & $\begin{array}{l}\text { The total number of shares investors have sold short but have not yet bought back. This information is available } \\
\text { monthly from Bloomberg. We normalize short interest by the total number of outstanding shares for each company. }\end{array}$ & Bloomberg \\
\hline $\begin{array}{l}\text { Aggregate Short } \\
\text { Interest }\end{array}$ & $\begin{array}{l}\text { The aggregate short position in the markets (NASDAQ, AMEX and NYSE) is the sum of all short interest positions for } \\
\text { all firms. We normalize aggregate short interest by the total number of shares traded in the markets. }\end{array}$ & Bloomberg \\
\hline $\begin{array}{l}\text { Investment } \\
\text { Bank Ranking }\end{array}$ & Ranking of investment banks and brokerage houses by Vault. & Vault Investment Bank Guide \\
\hline $\begin{array}{l}\text { All- Star } \\
\text { Analyst }\end{array}$ & $\begin{array}{l}\text { A dummy variable indicating whether or not the analyst appears as an All-American All-Star analyst according to the } \\
\text { annual survey in Institutional Investor magazine. }\end{array}$ & Institutional Investor Magazine \\
\hline
\end{tabular}




\section{Table 2 - Who Detects Corporate Fraud?}

This table identifies the actor that first brings the fraud to light. Internal governance includes frauds where the detector is the firm (e.g. press release), company management, or the board of directors. Analysts include both sell-side analysts from brokerage houses and buy-side analysts. Non-financial-market regulators include industry regulators (e.g. FERC, FAA, FDA) and other government agencies (e.g., State attorney general's offices). Strategic players include buyers, suppliers and competitors to the firm. We identify the actor as the media if information is first revealed in a print media outlet identified through FACTIVA (newspaper and/or magazine) where the story does not indicate another actor as the principal source of information.

\begin{tabular}{|c|c|c|c|c|}
\hline & & & Count & $\%$ of Total \\
\hline Total Internal Governance & & & 74 & $32.2 \%$ \\
\hline External Governance & $\begin{array}{c}\text { Count of External } \\
\text { Governance }\end{array}$ & $\begin{array}{l}\text { \% of External } \\
\text { Governance }\end{array}$ & & \\
\hline \multicolumn{5}{|l|}{ Mandated Actors } \\
\hline Non-Financial Market Regulators & 25 & $16.0 \%$ & & \\
\hline Auditors & 22 & $14.1 \%$ & & \\
\hline SEC & 9 & $5.8 \%$ & & \\
\hline Total Mandated Actors & 56 & $35.9 \%$ & & \\
\hline \multicolumn{5}{|l|}{ Market Actors } \\
\hline Employees & 30 & $19.2 \%$ & & \\
\hline Media & 25 & $16.0 \%$ & & \\
\hline Analysts & 23 & $14.7 \%$ & & \\
\hline Strategic Players & 11 & $7.1 \%$ & & \\
\hline Equity Holders & 5 & $3.2 \%$ & & \\
\hline Professional Service Firms & 4 & $2.6 \%$ & & \\
\hline Short Sellers & 2 & $1.3 \%$ & & \\
\hline Total Market Actors & 100 & $64.1 \%$ & & \\
\hline Total External Governance & & $100 \%$ & 156 & $67.8 \%$ \\
\hline Total Cases & & & 230 & \\
\hline
\end{tabular}




\section{Table 3 - Are Short Sellers Involved in Fraud Detection?}

This table examines whether short interest helps to predict fraud detection. The data consists of an unbalanced panel of monthly observations for each company in our sample from 1994 until 2005. The dependent variable takes the value of 1 if a fraud is detected and zero otherwise. Column 1 independent variables are the short interest for the company one month earlier and aggregate short interest. Short interest and aggregate short interest are divided by the number of share outstanding for (respectively) the firm and the market. In column 2 we interact lag short interest with whistleblower type and include but do not report controls for the type of fraud (restatement dummy, self-dealing dummy, other non-financial illegal activity dummy, misrepresentations on financial statements dummy, failure to disclose dummy). In column 3, we include firm fixed effects, and do not include controls for the type of fraud. In column 4, each row is a separate logistic regression where the logistic is only fitted for that type of detector. (Column 4 allows the sensitivity of detection to the controls to vary by detector type.) All regressions include NeweyWest Standard Errors to correct for serial correlation in the panel. ***,**, and ** denote significance at the $1 \%, 5 \%$, and $10 \%$ levels respectively. We exclude two observations for where shortsellers are identified as the fraud detector.

Logistic Regression

\begin{tabular}{|c|c|c|c|c|}
\hline \multicolumn{5}{|c|}{$\begin{array}{c}\text { Logistic Regression } \\
\text { Dependent Variable: Dummy for Fraud Detected in Period }\end{array}$} \\
\hline \multirow{3}{*}{ Lag Short Interest (All) } & 1 & 2 & 3 & 4 \\
\hline & $3.53 * * *$ & & & $4.92 *$ \\
\hline & $(0.94)$ & & & $(2.90)$ \\
\hline \multirow{2}{*}{ Lag Short Interest (Auditors) } & & $4.06 * *$ & 2.93 & 1.24 \\
\hline & & $(1.60)$ & $(4.37)$ & $(6.77)$ \\
\hline \multirow[t]{2}{*}{ Lag Short Interest (Equity Holders) } & & -15.36 & -20.84 & -53.94 \\
\hline & & $(14.95)$ & $(35.27)$ & $(36.26)$ \\
\hline \multirow[t]{2}{*}{ Lag Short Interest (Analysts) } & & 7.29 & 10.87 & $11.68^{* *}$ \\
\hline & & $(5.18)$ & $(8.18)$ & $(4.80)$ \\
\hline \multirow[t]{2}{*}{ Lag Short Interest (Strategic Players) } & & $6.63 * *$ & $12.17^{*}$ & $13.32 * * *$ \\
\hline & & $(3.17)$ & $(6.48)$ & $(4.83)$ \\
\hline \multirow[t]{2}{*}{ Lag Short Interest (Media) } & & $7.18^{* *}$ & 7.41 & $7.87^{*}$ \\
\hline & & $(3.41)$ & $(4.90)$ & $(4.78)$ \\
\hline \multirow[t]{2}{*}{ Lag Short Interest (SEC) } & & 7.39 & 10.41 & 7.93 \\
\hline & & $(11.76)$ & $(16.50)$ & $(21.37)$ \\
\hline \multicolumn{5}{|l|}{ Lag Short Interest (Non Financial Market } \\
\hline Regulators) & & $\begin{array}{l}-3.60 \\
(5.92)\end{array}$ & $\begin{array}{c}-4.83 \\
(11.05)\end{array}$ & $\begin{array}{l}-7.81 \\
(9.08)\end{array}$ \\
\hline Lag Short Interest (Employees) & & $\begin{array}{c}1.61 \\
(1.95)\end{array}$ & $\begin{array}{c}2.30 \\
(3.10)\end{array}$ & $\begin{array}{l}2.80 \\
(285)\end{array}$ \\
\hline Lag Short Interest (Lawyers, Insurance) & & $\begin{array}{c}4.82 \\
(3.27)\end{array}$ & $\begin{array}{l}7.77 \\
(7.36)\end{array}$ & $\begin{array}{c}5.31 \\
(4.24)\end{array}$ \\
\hline Aggregate Market Short / Shares Market & $\begin{array}{c}138.4 * * * \\
(21.65)\end{array}$ & $\begin{array}{c}140.1 * * * \\
(22.01)\end{array}$ & $\begin{array}{c}165.1 * * * \\
(26.71)\end{array}$ & Varies \\
\hline Pseudo R-Square & 0.037 & 0.042 & 0.038 & Varies \\
\hline Observations & 14546 & 14546 & 13594 & $\begin{array}{c}\text { from } 418 \text { to } \\
14546\end{array}$ \\
\hline Included Whistleblower Type Effects & No & Yes & No & No \\
\hline Included Dummies for Restated & No & Yes & No & Yes \\
\hline Included Type of Fraud Dummies & No & Yes & No & Yes \\
\hline Included Firm Fixed Effects & No & No & Yes & Yes \\
\hline
\end{tabular}




\section{Table 4 - Who Detects Corporate Fraud after Accounting for Probable Detections by Short Sellers}

This table revises our original counts for fraud detectors (column 2) with new estimates (column 3) after reclassifying the fraud detector for eight observations where we found significant shortselling surrounding fraud detection (figure 1). The median durations of the frauds (columns 5 and 6) are in months, based on the class period, and capped at a maximum duration of 3 years. The median adjusted duration column is based on a regression (not presented) of duration on type of actor, including a dummy for financial restatements, and for the nature of the fraud (self-dealing, non-accounting related illegal activity, financial misrepresentations, and failure to disclose).

\begin{tabular}{lccc|cc}
\hline \multicolumn{2}{l}{ Panel A - Frequency and Duration } & \multicolumn{5}{l|}{} \\
\hline $\begin{array}{l}\text { Fraud Detector } \\
\text { (External mechanisms only) }\end{array}$ & $\begin{array}{c}\text { Original } \\
\text { Count }\end{array}$ & $\begin{array}{c}\text { Revised } \\
\text { Count }\end{array}$ & $\begin{array}{c}\text { Frequency } \\
\%\end{array}$ & $\begin{array}{c}\text { Median } \\
\text { Duration } \\
\text { (months) }\end{array}$ & $\begin{array}{c}\text { Median } \\
\text { Adjusted } \\
\text { Duration } \\
\text { (months) }\end{array}$ \\
$\begin{array}{l}\text { Mandated Actors } \\
\text { Non-Financial Market }\end{array}$ & 25 & 25 & $16.0 \%$ & 13.3 & 14.7 \\
$\begin{array}{l}\text { Regulators } \\
\text { Auditors }\end{array}$ & 22 & 21 & $13.5 \%$ & 14.7 & 13.9 \\
SEC & 9 & 9 & $5.8 \%$ & 21.2 & 20.4 \\
\cline { 2 - 6 }$\quad$ Total Mandated Actors & 56 & 55 & $35.3 \%$ & 15.8 & 16.4 \\
Market Actors & & & & & \\
Analysts & 23 & 21 & $13.5 \%$ & 8.4 & 10.8 \\
Short Sellers & 2 & 10 & $6.4 \%$ & 10.5 & 12.3 \\
Strategic Players & 11 & 10 & $6.4 \%$ & 13.3 & 15.5 \\
External Equity Holders & 5 & 5 & $3.2 \%$ & 15.9 & 15.2 \\
Employees & 30 & 30 & $19.2 \%$ & 20.9 & 22.9 \\
Media & 25 & 21 & $13.5 \%$ & 21.0 & 20.2 \\
Insurance, Plaintiff Law Firms & 4 & 4 & $2.6 \%$ & 31.4 & 30.8 \\
\cline { 2 - 6 }$\quad$ Total Market Actors & 100 & 101 & $64.7 \%$ & 15.0 & 15.5 \\
\hline Overall Totals & 156 & 156 & & 15.0 & \\
\hline
\end{tabular}




\section{Table 5 - Does the Distribution of Fraud Detectors Vary With the Nature of the Fraud, Industry, and Settlement Amount?}

This table explores the robustness of the distribution of fraud detectors controlling for other factors. Panel A breaks down the fraud by whether they involved self-dealing, other illegal activities, or if the fraud primarily involved a failure to disclose (about the past or the future) or financial misrepresentations (about the past or the future). Panel B breaks down the revised distribution of fraud detectors by whether the fraud required the firm to file restated financial statements with the SEC or not. The median duration is the median for the category. Panel $\mathrm{C}$ breaks down the revised distribution of fraud detectors by whether the company is regulated or not. The median duration is the median for the category. Panel D explores whether the distribution is influenced by the settlement amount.

\begin{tabular}{|c|c|c|c|c|}
\hline & Self Dealing & Other Illegal & $\begin{array}{c}\text { Failure to } \\
\text { Disclose }\end{array}$ & $\begin{array}{c}\text { Misrepresent- } \\
\text { ation }\end{array}$ \\
\hline \multicolumn{5}{|l|}{ Mandated Actors } \\
\hline $\begin{array}{l}\text { Non-Financial Market } \\
\text { Regulators }\end{array}$ & $\begin{array}{l}9.1 \% \\
(1)\end{array}$ & $\begin{array}{c}40.9 \% \\
(9)\end{array}$ & $\begin{array}{c}10.0 \% \\
(9)\end{array}$ & $\begin{array}{l}26.1 \% \\
(6)\end{array}$ \\
\hline Auditors & $\begin{array}{c}18.2 \% \\
(2)\end{array}$ & $\begin{array}{c}4.5 \% \\
(1)\end{array}$ & $\begin{array}{c}18.9 \% \\
(17)\end{array}$ & $\begin{array}{c}4.3 \% \\
(1)\end{array}$ \\
\hline SEC & - & $\begin{array}{c}4.5 \% \\
(1)\end{array}$ & $\begin{array}{c}7.8 \% \\
(7)\end{array}$ & $\begin{array}{c}4.3 \% \\
(1)\end{array}$ \\
\hline Total Mandated Actors & $\begin{array}{l}27.3 \% \\
(3)\end{array}$ & $\begin{array}{l}50.0 \% \\
(11)\end{array}$ & $\begin{array}{l}25.6 \% \\
(23)\end{array}$ & $\begin{array}{l}34.8 \% \\
(8)\end{array}$ \\
\hline \multicolumn{5}{|l|}{ Market Actors } \\
\hline Analysts & - & - & $\begin{array}{c}18.9 \% \\
(17)\end{array}$ & $\begin{array}{c}17.4 \% \\
(4)\end{array}$ \\
\hline Short Seller & $\begin{array}{c}9.1 \% \\
(1)\end{array}$ & $\begin{array}{c}4.5 \% \\
(1)\end{array}$ & $\begin{array}{l}7.8 \% \\
(7)\end{array}$ & $\begin{array}{c}4.3 \% \\
(1)\end{array}$ \\
\hline Strategic Players & - & $\begin{array}{c}9.1 \% \\
(2)\end{array}$ & $\begin{array}{c}7.8 \% \\
(7)\end{array}$ & $\begin{array}{l}4.3 \% \\
(1)\end{array}$ \\
\hline External Equity Holders & $\begin{array}{l}9.1 \% \\
(1)\end{array}$ & - & $\begin{array}{c}3.3 \% \\
(3)\end{array}$ & $\begin{array}{c}4.33 \% \\
(1)\end{array}$ \\
\hline Employees & $\begin{array}{c}18.2 \% \\
(2)\end{array}$ & $\begin{array}{c}31.8 \% \\
(7)\end{array}$ & $\begin{array}{c}16.7 \% \\
(15)\end{array}$ & $\begin{array}{c}26.1 \% \\
(6)\end{array}$ \\
\hline Media & $\begin{array}{c}18.2 \% \\
(2)\end{array}$ & $\begin{array}{c}4.5 \% \\
(1)\end{array}$ & $\begin{array}{c}17.8 \% \\
(16)\end{array}$ & $\begin{array}{c}8.7 \% \\
(2)\end{array}$ \\
\hline Professional Service & $\begin{array}{c}18.2 \% \\
(2)\end{array}$ & - & $\begin{array}{c}2.2 \% \\
(2)\end{array}$ & - \\
\hline Total Market Actors & $\begin{array}{c}72.7 \% \\
(8)\end{array}$ & $\begin{array}{c}50.0 \% \\
(11) \\
\end{array}$ & $\begin{array}{l}74.4 \% \\
(67) \\
\end{array}$ & $\begin{array}{c}65.2 \% \\
(15)\end{array}$ \\
\hline Percentage of all (Total) & $\begin{array}{l}7.1 \% \\
(11)\end{array}$ & $\begin{array}{l}14.2 \% \\
(22)\end{array}$ & $\begin{array}{l}57.7 \% \\
(90)\end{array}$ & $\begin{array}{l}14.7 \% \\
(23)\end{array}$ \\
\hline
\end{tabular}




\begin{tabular}{|c|c|c|c|c|}
\hline \multirow[b]{3}{*}{ Mandated Actors } & \multicolumn{2}{|c|}{ Not Restated Financials } & \multicolumn{2}{|c|}{ Restated Financials } \\
\hline & Count & Frequency $\%$ & Count & Frequency $\%$ \\
\hline & & & & \\
\hline Non-Financial Market Regulators & 13 & $22.0 \%$ & 12 & $12.4 \%$ \\
\hline Auditors & 3 & $5.1 \%$ & 18 & $18.6 \%$ \\
\hline SEC & 0 & $0.0 \%$ & 9 & $9.3 \%$ \\
\hline Total Mandated & \multicolumn{3}{|c|}{$27.1 \%$} & $40.3 \%$ \\
\hline \multicolumn{5}{|l|}{ Market Actors } \\
\hline Analysts & 12 & $20.3 \%$ & 9 & $9.3 \%$ \\
\hline Short Seller & 4 & $6.8 \%$ & 6 & $6.2 \%$ \\
\hline Strategic Players & 5 & $8.5 \%$ & 5 & $5.2 \%$ \\
\hline External Equity Holders & 2 & $3.4 \%$ & 3 & $3.1 \%$ \\
\hline Employees & 10 & $16.9 \%$ & 20 & $20.6 \%$ \\
\hline Media & 8 & $13.6 \%$ & 13 & $13.4 \%$ \\
\hline Professional Service Firms & 2 & $3.4 \%$ & 2 & $2.1 \%$ \\
\hline Total Market & & $72.9 \%$ & & $59.7 \%$ \\
\hline Total (\% of sample) & 59 & \multirow[t]{2}{*}{$37.8 \%$} & 97 & \multirow[t]{2}{*}{$62.2 \%$} \\
\hline Median Duration & 11.6 & & 16.7 & \\
\hline
\end{tabular}

\begin{tabular}{|c|c|c|c|c|}
\hline & \multicolumn{2}{|c|}{ Not Regulated Industry } & \multicolumn{2}{|c|}{ Regulated Industry } \\
\hline & Count & Frequency $\%$ & Count & Frequency $\%$ \\
\hline \multicolumn{5}{|l|}{ Mandated Actors } \\
\hline Non-Financial Market Regulators & 4 & $6.3 \%$ & 21 & $23.6 \%$ \\
\hline Auditors & 10 & $15.9 \%$ & 11 & $12.4 \%$ \\
\hline SEC & 3 & $4.8 \%$ & 6 & $6.7 \%$ \\
\hline Total Mandated & \multicolumn{3}{|c|}{$27.0 \%$} & $42.7 \%$ \\
\hline \multicolumn{5}{|l|}{ Market Actors } \\
\hline$\overline{\text { Analysts }}$ & 11 & $17.5 \%$ & 10 & $11.2 \%$ \\
\hline Short Seller & 6 & $9.5 \%$ & 4 & $4.5 \%$ \\
\hline Clients, Competitors, Suppliers & 4 & $6.3 \%$ & 6 & $6.7 \%$ \\
\hline External Equity Holders & 3 & $4.8 \%$ & 2 & $2.2 \%$ \\
\hline Employees & 14 & $22.2 \%$ & 16 & $18.0 \%$ \\
\hline Media & 8 & $12.7 \%$ & 13 & $14.6 \%$ \\
\hline Insurance, Plaintiff Law Firms & 1 & $1.6 \%$ & 3 & $3.4 \%$ \\
\hline Total Market & & $73.0 \%$ & & $57.3 \%$ \\
\hline Total & \multirow{2}{*}{\multicolumn{2}{|c|}{$\begin{array}{c}64 \\
14.1\end{array}$}} & \multicolumn{2}{|l|}{92} \\
\hline Median Duration & & & 16.0 & \\
\hline \multicolumn{5}{|c|}{ Chi-Squared Test for Median Equivalence of Regulated vs Non-Regulated: $\chi(1)=0.66$ pvalue $=0.416$} \\
\hline
\end{tabular}




\begin{tabular}{|c|c|c|c|c|c|c|c|c|}
\hline \multicolumn{9}{|c|}{ Panel D-Breakdown by Settlement Amount } \\
\hline & All E & $\begin{array}{l}\text { ernal } \\
\text { es }\end{array}$ & $\begin{array}{r}\text { With S } \\
\text { Ar }\end{array}$ & $\begin{array}{l}\text { lement } \\
\text { unt }\end{array}$ & $\begin{array}{l}\text { With } S \\
>\$ 10\end{array}$ & $\begin{array}{l}\text { lement } \\
\text { illion }\end{array}$ & $\begin{array}{r}\text { With S } \\
>\$ 50\end{array}$ & $\begin{array}{l}\text { tlement } \\
\text { illion }\end{array}$ \\
\hline & Count & Freq \% & Count & Freq $\%$ & Count & Freq \% & Count & Freq $\%$ \\
\hline \multicolumn{9}{|l|}{ Mandated Actors } \\
\hline \multicolumn{9}{|l|}{$\overline{\text { Non-Financial }}$} \\
\hline Market & 25 & $16.0 \%$ & 18 & $15.4 \%$ & 16 & $17.4 \%$ & 9 & $21.4 \%$ \\
\hline \multicolumn{9}{|l|}{ Regulators } \\
\hline Auditors & 21 & 13.5 & 16 & 13.7 & 11 & 12.0 & 2 & 4.8 \\
\hline SEC & 9 & 5.8 & 6 & 5.1 & 2 & 2.2 & 0 & 0.0 \\
\hline Total Mandated & 55 & $35.3 \%$ & 40 & $34.2 \%$ & 29 & $31.5 \%$ & 11 & $26.2 \%$ \\
\hline \multicolumn{9}{|l|}{ Market Actors } \\
\hline$\overline{\text { Analysts }}$ & 21 & 13.5 & 16 & 13.7 & 13 & 14.1 & 6 & 14.3 \\
\hline Short Seller & 10 & 6.4 & 8 & 6.8 & 8 & 8.7 & 5 & 11.9 \\
\hline Strategic Players & 10 & 6.4 & 8 & 6.8 & 3 & 3.3 & 1 & 2.4 \\
\hline $\begin{array}{l}\text { External Equity } \\
\text { Holders }\end{array}$ & 5 & 3.2 & 4 & 3.4 & 4 & 4.4 & 2 & 4.8 \\
\hline Employees & 30 & 19.2 & 22 & 18.8 & 20 & 21.7 & 7 & 16.7 \\
\hline Media & 21 & 13.5 & 17 & 14.5 & 14 & 15.2 & 9 & 21.4 \\
\hline $\begin{array}{l}\text { Professional } \\
\text { Service }\end{array}$ & 4 & 2.6 & 2 & 1.7 & 1 & 1.1 & 1 & 2.4 \\
\hline Total Market & 101 & $64.7 \%$ & 77 & $65.8 \%$ & 63 & $68.5 \%$ & 31 & $73.8 \%$ \\
\hline Overall Total & 156 & & 117 & & 92 & & 42 & \\
\hline
\end{tabular}




\section{Table 6 - Does Fraud Detection involve Other Actors?}

For each case detected by an original fraud detector, we identify in the columns to the right "to whom" the whistle was blown (i.e. the next actor who played a central role in bringing the fraud to light). The percentages sum to 100 across the columns and reflect the relative importance for the original fraud detector in that row. The "public" category indicates that the original detector did not involve any other actor in bringing the fraud to light. The "firm" category captures situations where the firm comes forward with information about fraud that was initiated by actions by another actor.

\begin{tabular}{|c|c|c|c|c|c|c|c|c|}
\hline \multirow{2}{*}{$\begin{array}{c}\begin{array}{c}\text { Original } \\
\text { fraud } \\
\text { detector }\end{array} \\
\end{array}$} & \multicolumn{8}{|c|}{ To whom is the whistle blown? } \\
\hline & Media & $\begin{array}{l}\text { Non Fin'l } \\
\text { Regulator }\end{array}$ & $S E C$ & Lawyers & Analyst & $\begin{array}{c}\text { Other } \\
\text { External }\end{array}$ & Public & Firm \\
\hline \multicolumn{9}{|c|}{ Mandated Actors } \\
\hline $\begin{array}{l}\text { NonFinancial } \\
\text { Regulators }\end{array}$ & $\begin{array}{c}20.0 \% \\
(5)\end{array}$ & $\begin{array}{c}12.0 \% \\
(3)\end{array}$ & -- & -- & $\begin{array}{l}4.0 \% \\
(1)\end{array}$ & -- & $\begin{array}{l}8.0 \% \\
(2)\end{array}$ & $\begin{array}{c}56.0 \% \\
(14)\end{array}$ \\
\hline Auditors & $\begin{array}{c}4.8 \% \\
(1)\end{array}$ & -- & -- & -- & -- & -- & -- & $\begin{array}{c}95.2 \% \\
(20)\end{array}$ \\
\hline SEC & $\begin{array}{c}22.2 \% \\
(2)\end{array}$ & -- & & -- & -- & -- & $\begin{array}{c}66.7 \% \\
(6)\end{array}$ & $\begin{array}{c}11.1 \% \\
(1)\end{array}$ \\
\hline \multicolumn{9}{|l|}{ Market Actors } \\
\hline Analysts & $\begin{array}{c}57.1 \% \\
(12)\end{array}$ & -- & -- & -- & -- & -- & $\begin{array}{c}38.1 \% \\
(8)\end{array}$ & $\begin{array}{c}4.8 \% \\
(1)\end{array}$ \\
\hline Short Sellers & $\begin{array}{c}60.0 \% \\
(6)\end{array}$ & -- & -- & -- & $\begin{array}{l}20.0 \% \\
\text { (2) }\end{array}$ & $\begin{array}{l}20.0 \% \\
\text { (2) }\end{array}$ & -- & -- \\
\hline $\begin{array}{l}\text { Strategic } \\
\text { Players }\end{array}$ & $\begin{array}{c}30.0 \% \\
(3)\end{array}$ & $\begin{array}{c}20.0 \% \\
(2)\end{array}$ & -- & -- & -- & -- & -- & $\begin{array}{c}50.0 \% \\
(5)\end{array}$ \\
\hline $\begin{array}{l}\text { Equity } \\
\text { Holders }\end{array}$ & $\begin{array}{c}80.0 \% \\
\text { (4) }\end{array}$ & -- & -- & -- & -- & -- & -- & $\begin{array}{c}20.0 \% \\
\text { (1) }\end{array}$ \\
\hline Employees & $\begin{array}{c}3.3 \% \\
(1)\end{array}$ & $\begin{array}{c}33.3 \% \\
(10)\end{array}$ & $\begin{array}{c}10.0 \% \\
(3)\end{array}$ & $\begin{array}{c}13.3 \% \\
(4)\end{array}$ & -- & $\begin{array}{c}3.3 \% \\
(1)\end{array}$ & -- & $\begin{array}{c}36.7 \% \\
(11)\end{array}$ \\
\hline Media & & $\begin{array}{c}4.8 \% \\
(1)\end{array}$ & -- & -- & -- & -- & $\begin{array}{c}95.2 \% \\
(20)\end{array}$ & -- \\
\hline $\begin{array}{l}\text { Law Firms, } \\
\text { Insurance }\end{array}$ & $\begin{array}{c}50.0 \% \\
(2) \\
\end{array}$ & -- & -- & -- & -- & -- & -- & $\begin{array}{c}50.0 \% \\
(2) \\
\end{array}$ \\
\hline $\begin{array}{l}\text { Column } \\
\text { Total }\end{array}$ & $\begin{array}{c}23.1 \% \\
(36)\end{array}$ & $\begin{array}{c}10.3 \% \\
(16)\end{array}$ & $\begin{array}{c}1.9 \% \\
(3)\end{array}$ & $\begin{array}{c}2.6 \% \\
(4)\end{array}$ & $\begin{array}{c}1.9 \% \\
(3)\end{array}$ & $\begin{array}{c}1.9 \% \\
(3)\end{array}$ & $\begin{array}{c}23.1 \% \\
(36)\end{array}$ & $\begin{array}{c}35.3 \% \\
(55)\end{array}$ \\
\hline
\end{tabular}




\section{Table 7 - Source of Information}

For each case, we assess where the information that is lead to the revelation originates from. We first categorize whether the information comes from SEC Financial Market Disclose, usually via quarterly reporting. Then, for those cases in which the information is not from SEC disclosure rules, we break down whether the information is collectible public information (e.g., a survey by analysts), regulatory discovery findings, or information from internal firm operations. Percentages of each of these categories are presented for each whistleblower with the frequency counts in parentheses.

\begin{tabular}{|c|c|c|c|c|c|}
\hline & $\begin{array}{l}\text { Financial } \\
\text { Market }\end{array}$ & Non-Fir & ial Market I & osures & \\
\hline & & $\begin{array}{l}\text { Collectible } \\
\text { Public } \\
\text { Information }\end{array}$ & $\begin{array}{l}\text { Regulator } \\
\text { Discovery }\end{array}$ & $\begin{array}{l}\text { Internal to } \\
\text { Firm }\end{array}$ & Count \\
\hline \multicolumn{6}{|l|}{ Mandated Actors } \\
\hline $\begin{array}{l}\text { Non-Financial Market } \\
\text { Actors }\end{array}$ & $\begin{array}{l}12.0 \% \\
(3)\end{array}$ & $\begin{array}{l}16.0 \% \\
(4)\end{array}$ & $\begin{array}{l}68.0 \% \\
(17)\end{array}$ & $\begin{array}{l}4.0 \% \\
(1)\end{array}$ & 25 \\
\hline Auditors & $\begin{array}{l}9.5 \% \\
(2)\end{array}$ & -- & -- & $\begin{array}{l}90.5 \% \\
(19)\end{array}$ & 21 \\
\hline SEC & $\begin{array}{c}100.0 \% \\
(9)\end{array}$ & -- & -- & -- & 9 \\
\hline \multicolumn{6}{|l|}{ Market Actors } \\
\hline Analysts & $\begin{array}{c}66.7 \% \\
(14)\end{array}$ & $\begin{array}{l}19.0 \% \\
(4)\end{array}$ & -- & $\begin{array}{l}14.3 \% \\
(3)\end{array}$ & 21 \\
\hline Short Seller & $\begin{array}{l}70.0 \% \\
(7)\end{array}$ & $\begin{array}{l}10.0 \% \\
(1)\end{array}$ & -- & $\begin{array}{l}20.0 \% \\
(2)\end{array}$ & 10 \\
\hline Strategic Players & $\begin{array}{l}40.0 \% \\
(4)\end{array}$ & $\begin{array}{l}10.0 \% \\
(1)\end{array}$ & $\begin{array}{l}30.0 \% \\
(3)\end{array}$ & $\begin{array}{l}20.0 \% \\
(2)\end{array}$ & 10 \\
\hline $\begin{array}{l}\text { External Equity } \\
\text { Holders }\end{array}$ & $\begin{array}{l}80.0 \% \\
(4)\end{array}$ & -- & -- & $\begin{array}{l}20.0 \% \\
(1)\end{array}$ & 5 \\
\hline Employees & $\begin{array}{l}3.3 \% \\
(1)\end{array}$ & -- & $\begin{array}{l}10.0 \% \\
(3)\end{array}$ & $\begin{array}{l}86.7 \% \\
(26)\end{array}$ & 30 \\
\hline Media & $\begin{array}{l}71.4 \% \\
(15)\end{array}$ & $\begin{array}{l}4.8 \% \\
(1)\end{array}$ & $\begin{array}{l}4.8 \% \\
(1)\end{array}$ & $\begin{array}{l}19.0 \% \\
(4)\end{array}$ & 21 \\
\hline Professional Service & $\begin{array}{l}50.0 \% \\
(2)\end{array}$ & $\begin{array}{l}50.0 \% \\
(2)\end{array}$ & -- & -- & 4 \\
\hline Total & $\begin{array}{c}39.1 \% \\
(61)\end{array}$ & $\begin{array}{l}8.3 \% \\
(13)\end{array}$ & $\begin{array}{c}15.4 \% \\
(24) \\
\end{array}$ & $\begin{array}{c}37.2 \% \\
(58)\end{array}$ & 156 \\
\hline
\end{tabular}




\section{Table 8 - What is the Impact of Fraud Detection on an Analyst's Career?}

\section{Panel A: Unconditional Probability of Being All American All-Star Analyst}

Panel A presents the unconditional probability that an analyst who reveals a fraud is an "All-Star" analyst in the year prior to fraud detection, as categorized by Institutional Investor magazine. We categorize analysts as Yes or No for the rating if we know the analyst name detecting the fraud and use the category Unknown if no specific name is provided for the analyst.

\begin{tabular}{cc}
\hline \multicolumn{2}{c}{ Unconditional Probability of Being All-Star Analyst } \\
\hline Superstar Before & \\
No & 0.717 \\
Yes & 0.239 \\
Unknown & 0.043 \\
\hline
\end{tabular}

\section{Panel B: Transition Probability of Being All American All-Star Analyst}

Panel B presents the transition probability of an analyst remaining in their All-Star category or moving to other All-Star categories in the year after the fraud detection for each ex ante All-Star category. The blank fields indicate that no analysts who were in the Yes or Unknown All-Star categories moved to a different category.

\begin{tabular}{cccc}
\hline \multicolumn{4}{c}{ Transition Probability of Moving All-Star Categories - Year Prior to Fraud to Year After } \\
\hline & Superstars After & \\
Superstar Before & No & Yes & Unknown \\
No & 0.818 & 0.061 & 0.121 \\
Yes & -- & 1 & -- \\
Unknown & -- & -- & 1 \\
\hline
\end{tabular}


Table 9 - Who in the Media Detects Fraud?

For each case in which the media is the fraud detector, the table records the newspaper or journal that reveals the fraud, the reporter(s) of the article, the page on which the article appears, and comments about the status and specialization of the reporter(s), where available.

\begin{tabular}{|c|c|c|c|c|}
\hline Company & News Outlet & Reporter & Article Location & Reporter Status \\
\hline Allegheny Energy & New York Times & David Barboza & page 1 & \\
\hline $\begin{array}{l}\text { AOL Time Warner, } \\
\text { Inc. }\end{array}$ & New York Times & $\begin{array}{l}\text { Gretchen } \\
\text { Morgenson }\end{array}$ & page 1 , business & $\begin{array}{l}\text { staff writer, specialist } \\
\text { on governance }\end{array}$ \\
\hline $\begin{array}{l}\text { Computer } \\
\text { Associates }\end{array}$ & New York Times & Alex Berenson & page 1 , business & $\begin{array}{l}\text { staff writer, author of } \\
\text { book on governance }\end{array}$ \\
\hline $\begin{array}{l}\text { Halliburton } \\
\text { Company }\end{array}$ & New York Times & $\begin{array}{l}\text { Alex Berenson } \\
\text { and Lowell } \\
\text { Bergaman }\end{array}$ & page 1 , business & $\begin{array}{l}\text { staff writer, author of } \\
\text { book on governance }\end{array}$ \\
\hline Sprint Corporation & New York Times & $\begin{array}{l}\text { David Cay } \\
\text { Johnston }\end{array}$ & page 25 , section 1 & $\begin{array}{l}\text { author of book on tax } \\
\text { avoidance by } \\
\text { corporations }\end{array}$ \\
\hline $\begin{array}{l}\text { Ascend } \\
\text { Communications }\end{array}$ & $\begin{array}{l}\text { San Francisco } \\
\text { Chronicle }\end{array}$ & Herb Greenberg & page 1 , business & $\begin{array}{l}\text { staff writer, specialist } \\
\text { on tech sector }\end{array}$ \\
\hline $3 \mathrm{Com}$ & $\begin{array}{l}\text { San Francisco } \\
\text { Chronicle }\end{array}$ & Herb Greenberg & page 1 , business & $\begin{array}{l}\text { staff writer, specialist } \\
\text { on tech sector }\end{array}$ \\
\hline $\begin{array}{l}\text { Broadcom } \\
\text { Corporation }\end{array}$ & Wall Street Journal & Molly Williams & $\begin{array}{l}\text { C11, Heard on the } \\
\text { Street }\end{array}$ & staff writer \\
\hline Cardinal Health, Inc. & Wall Street Journal & Jonathan Weil & $\begin{array}{l}\text { C1, Heard on the } \\
\text { Street }\end{array}$ & $\begin{array}{l}\text { writes accounting } \\
\text { column for WSJ, }\end{array}$ \\
\hline Enron Corporation & Wall Street Journal & Jonathan Weil & $\begin{array}{l}\text { T1 - page } 1 \text { of } \\
\text { Texas Journal } \\
\text { (regional edition of } \\
\text { WSJ) }\end{array}$ & $\begin{array}{l}\text { writes accounting } \\
\text { column for WSJ, }\end{array}$ \\
\hline $\begin{array}{l}\text { E.W. Blanch } \\
\text { Holdings }\end{array}$ & Wall Street Journal & Deborah Lohse & A 10 & staff writer \\
\hline Raytheon Company & Wall Street Journal & $\begin{array}{l}\text { Deborah } \\
\text { Solomon, Steve } \\
\text { Liesman, Denis } \\
\text { Berman } \\
\text { no author }\end{array}$ & A1, B6 & staff writer \\
\hline AT\&T Corporation & Business Week & Robert Barker & $\begin{array}{l}\text { Investor column (p. } \\
264)\end{array}$ & \\
\hline Bausch \& Lomb & Business Week & Rochelle Sharpe & p 87 & \\
\hline Mattel, Inc. & Business Week & Kathleen Morris & $* *$ cover story** & \\
\hline Silicon Graphics & Business Week & $\begin{array}{l}\text { Robert D. Hof, } \\
\text { Ira Sager, Linda } \\
\text { Himelstein }\end{array}$ & $* *$ cover story** & \\
\hline Employee Solutions & Financial World & Debra Sparks & p 52 & $\begin{array}{l}\text { subsequently writer } \\
\text { for business week }\end{array}$ \\
\hline Apria Healthcare & Fortune & Erick Schonfeld & p 114 & \\
\hline $\begin{array}{l}\text { Charter } \\
\text { Communications }\end{array}$ & Cable World & Mavis Scanlon & $\mathrm{Na}$ & \\
\hline $\begin{array}{l}\text { Cambrex } \\
\text { Corporation }\end{array}$ & Chemical Reporter & $\mathrm{Na}$ & $\mathrm{Na}$ & \\
\hline $\begin{array}{l}\text { Long Island } \\
\text { Lighting Co. }\end{array}$ & $\begin{array}{l}\text { Daily Electricity } \\
\text { Reporter }\end{array}$ & $\mathrm{Na}$ & $\mathrm{Na}$ & \\
\hline $\begin{array}{l}\text { Bristol Myers } \\
\text { Squibb }\end{array}$ & Cancer Letter & $\mathrm{Na}$ & $\mathrm{Na}$ & \\
\hline Tyco International & SEC Insight & no author & $\mathrm{Na}$ & \\
\hline
\end{tabular}




\section{Table 10 - What are the Costs and Benefits for Employee Whistle Blowing?}

The table indicates for each employee whistleblower the following information: company (column 1); the whistleblower name and position, whether the whistleblower identifies herself (column 2); whether the whistleblower was terminated, quit, or was given a job with significantly reduced responsibility (column 3); other costs claimed by the employee (column 4); whether a lawsuit filed with potential for damages including the type of lawsuit (column 5); whether an outcome to the lawsuit (column 6); and other possible benefits of whistleblowing (column 7).

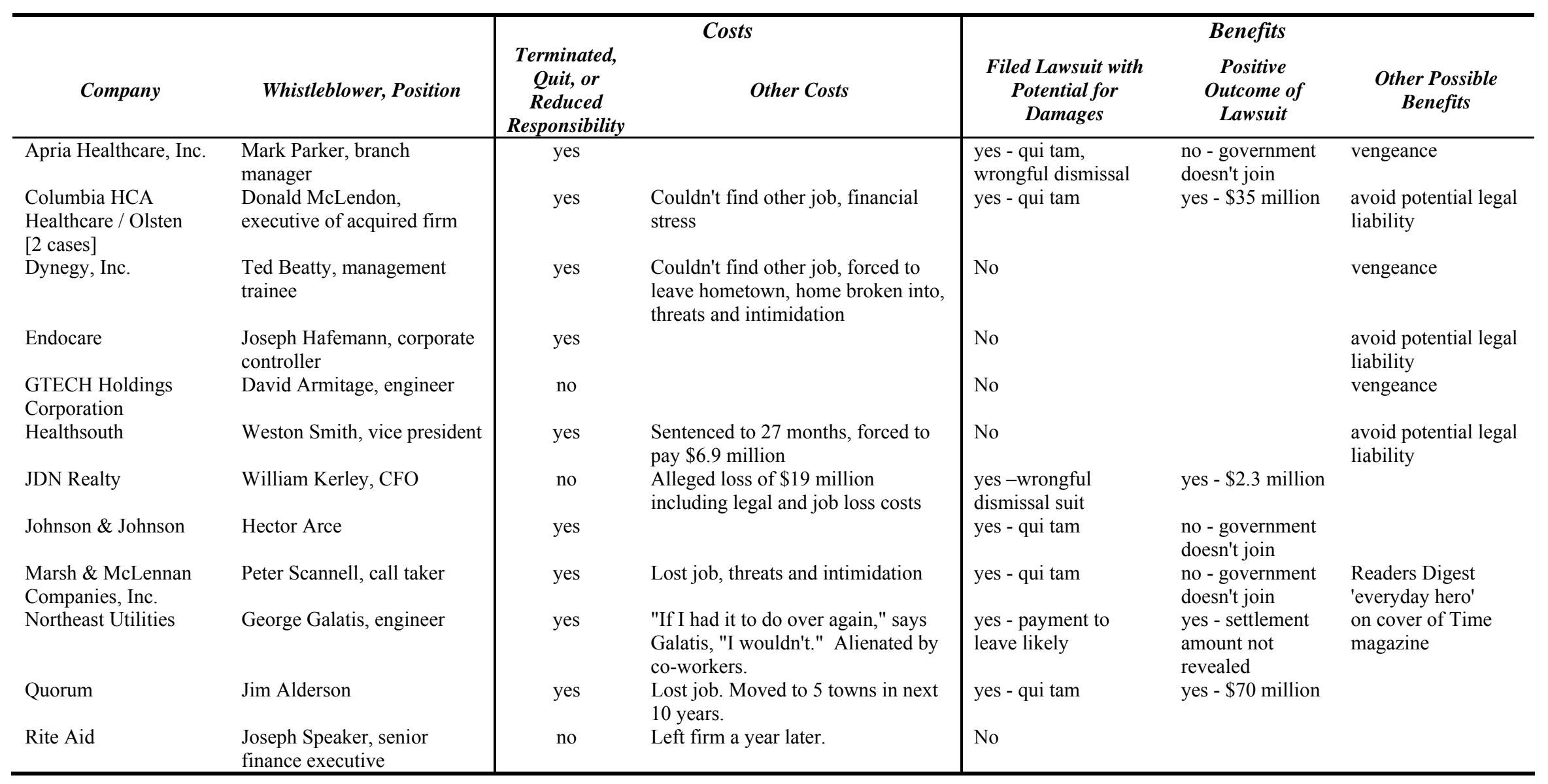




\begin{tabular}{|c|c|c|c|c|c|c|}
\hline Service Corporation & Charles Albert and Thomas & yes & & yes -wrongful & no information & \\
\hline Solectron Corporation & $\begin{array}{l}\text { Ronald Sorisho, division } \\
\text { CFO }\end{array}$ & yes & & $\begin{array}{l}\text { yes -wrongful } \\
\text { dismissal suit }\end{array}$ & no information & $\begin{array}{l}\text { avoid potential legal } \\
\text { liability }\end{array}$ \\
\hline Xerox Corporation & $\begin{array}{l}\text { James Bingham, assistant } \\
\text { treasurer }\end{array}$ & yes & $\begin{array}{l}\text { "... never get a job in Corporate } \\
\text { America again," Bingham's lawyer. }\end{array}$ & $\begin{array}{l}\text { yes - wrongful } \\
\text { dismissal suit }\end{array}$ & no information & $\begin{array}{l}\text { avoid potential legal } \\
\text { liability }\end{array}$ \\
\hline Ann Taylor & internal unknown & Unknown & & & & \\
\hline America West Holding & $\begin{array}{l}\text { Unionized maintenance } \\
\text { workers }\end{array}$ & Unknown & & & & $\begin{array}{l}\text { improve } \\
\text { employment }\end{array}$ \\
\hline Cendant Corporation & $\begin{array}{l}\text { Accounting staff integrating } \\
\text { newly acquired firm }\end{array}$ & Unknown & & & & $\begin{array}{l}\text { avoid potential legal } \\
\text { liability }\end{array}$ \\
\hline Ceridian & unnamed employee & Unknown & & & & \\
\hline Consol Energy & $\begin{array}{l}\text { internal unknown letter to } \\
\text { auditor and SEC }\end{array}$ & Unknown & & & & \\
\hline $\begin{array}{l}\text { Enterasys Networks, } \\
\text { Inc. }\end{array}$ & unnamed finance executive & Unknown & & & & \\
\hline Footstar, Inc. & Corporate Accounting group & Unknown & & & & $\begin{array}{l}\text { avoid potential legal } \\
\text { liability }\end{array}$ \\
\hline Laidlaw & internal unknown & Unknown & & & & \\
\hline Nicor, Inc. & anonymous letter & Unknown & & & & \\
\hline PhyCor, Inc. & Doctors who are employees & Unknown & & & & $\begin{array}{l}\text { improve } \\
\text { employment } \\
\text { conditions }\end{array}$ \\
\hline SUPERVALU, Inc. & $\begin{array}{l}\text { an unnamed female auditor } \\
\text { fired }\end{array}$ & Unknown & & & & $\begin{array}{l}\text { avoid potential legal } \\
\text { liability }\end{array}$ \\
\hline $\begin{array}{l}\text { Symbol Technologies } \\
\text { Tenet Healthcare }\end{array}$ & unknown letter to SEC & Unknown & & & & \\
\hline Corporation & unnamed employee & Unknown & & & & \\
\hline $\begin{array}{l}\text { Union Pacific } \\
\text { Corporation }\end{array}$ & Union action & Unknown & & & & $\begin{array}{l}\text { improve } \\
\text { employment } \\
\text { conditions }\end{array}$ \\
\hline
\end{tabular}




\section{Table 11 - Do Incentives Impact Employee Whistleblowing? Evidence from Qui- Tam Availability}

This table provides a breakdown of the distribution of fraud detector for the healthcare and non-healthcare industries, where healthcare includes medical treatments and supporting industries including pharmaceuticals and manufacturers of medical supplies and equipment. In many healthcare companies, the government is a significant buyer of company services, and consequently employees can possibly benefit from qui-tam lawsuits. The null hypothesis of the Chi-Square test is that the employee percentage of fraud detectors is the same for non-healthcare and healthcare industries.

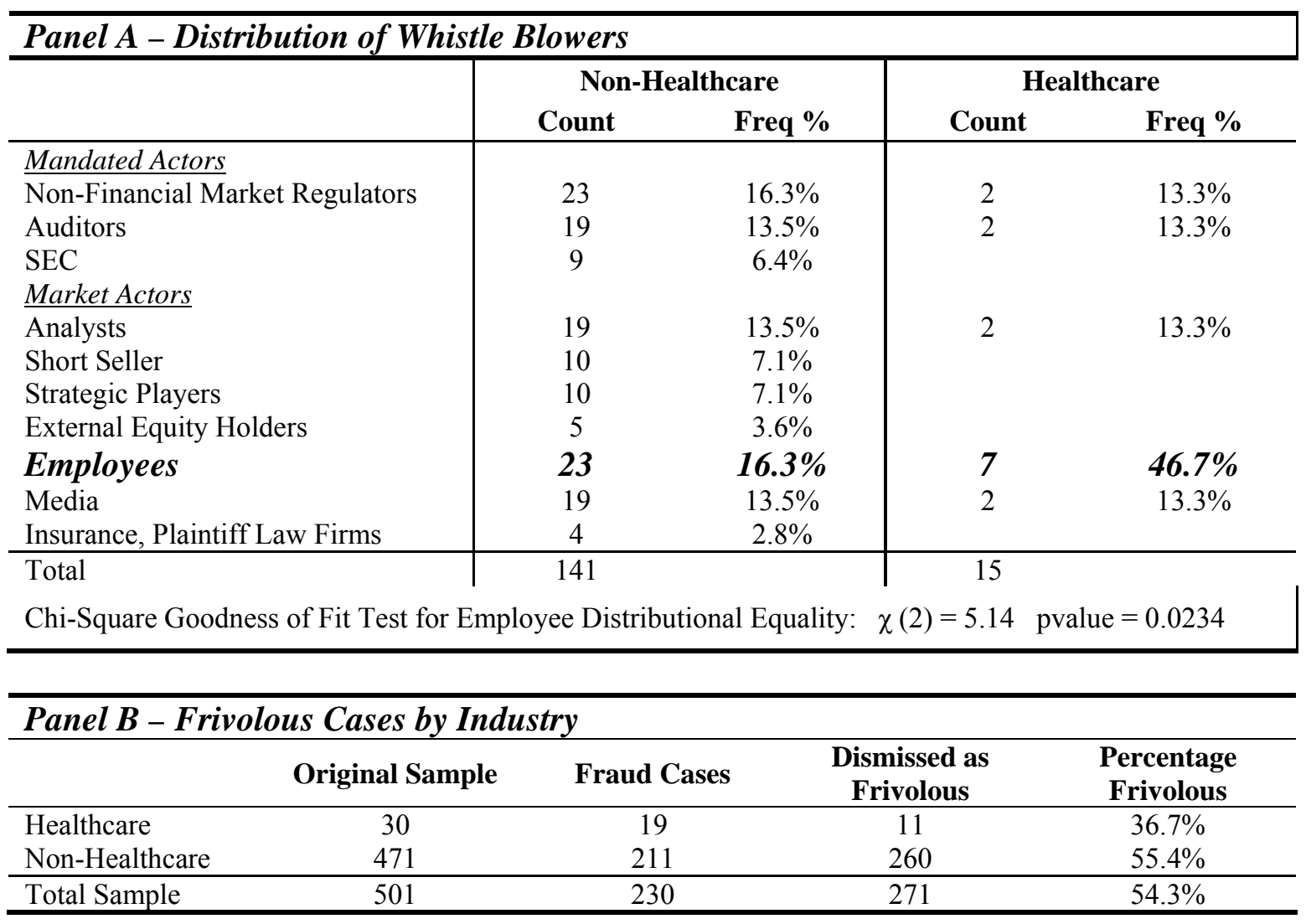




\section{Table 12 - Does Auditor Involvement in Detection Change post Enron?}

The table breaks down the frauds along two dimensions. The rows indicate whether the fraud in question required restatements filed with the SEC for the period in question (row 1) or did not require restatements (row 2). The columns provide details about the identity of the fraud detector, and how the relevance of this category of detector changes over time. Column 1 presents the percentage and count (in parentheses) of the 156 external frauds that required restatements, while column 2 repeats the exercise for the 21 cases where auditors were the fraud detectors (we do not include the two accounting cases we reclassified as shortsellers). In Columns 3 and 4, we breakdown the auditor cases over time, column 3 indicating the cases raised by auditors prior to Enron, and column 4 indicating those cases post Enron.

\begin{tabular}{|c|c|c|c|c|}
\hline $\begin{array}{l}\text { Accounting } \\
\text { Status of Fraud }\end{array}$ & $\begin{array}{l}\text { All Fraud } \\
\text { Detectors }\end{array}$ & Auditor & $\begin{array}{l}\text { Auditor } \\
\text { PreEnron }\end{array}$ & $\begin{array}{l}\text { Auditor } \\
\text { PostEnron }\end{array}$ \\
\hline $\begin{array}{l}\text { Required } \\
\text { Restatements }\end{array}$ & $\begin{array}{l}62.2 \% \\
(97)\end{array}$ & $\begin{array}{l}85.7 \% \\
(18)\end{array}$ & $\begin{array}{l}100 \% \\
(7)\end{array}$ & $\begin{array}{l}78.6 \% \\
(11)\end{array}$ \\
\hline $\begin{array}{l}\text { Not Required } \\
\text { Restatements }\end{array}$ & $\begin{array}{c}37.8 \% \\
(59)\end{array}$ & $\begin{array}{l}14.3 \% \\
(3)\end{array}$ & -- & $\begin{array}{l}21.4 \% \\
(3)\end{array}$ \\
\hline Totals & 156 External Cases & $\begin{array}{c}21 \text { Cases } \\
\text { of } 156 \text { External } \\
=13.55\end{array}$ & $\begin{array}{c}7 \text { Cases } \\
\text { of } 73 \text { Pre Enron } \\
=9.6 \%\end{array}$ & $\begin{array}{c}14 \text { Cases } \\
\text { of } 83 \text { Post Enron } \\
=16.9 \%\end{array}$ \\
\hline
\end{tabular}




\section{Table 13 - Impact of SOX on Fraud Detector Distribution}

This table provides the distribution of external fraud detectors before and after the passage of SarbanesOxley in July 2002.

\begin{tabular}{l|cc|cc}
\hline & \multicolumn{2}{|c|}{ Pre-SOX } & \multicolumn{2}{c}{ Post-Sox } \\
& Count & Freq \% & Count & Freq \% \\
\hline Mandated Actors & & & & \\
Non-Financial Market Regulators & 17 & $15.3 \%$ & 8 & $17.8 \%$ \\
Auditors & 8 & $7.2 \%$ & 13 & $28.9 \%$ \\
SEC & 5 & $4.5 \%$ & 4 & $8.9 \%$ \\
\hline \multicolumn{1}{c|}{ Total Mandated Actors } & 30 & $27.1 \%$ & 25 & $55.6 \%$ \\
\hline Analysts & 16 & $14.4 \%$ & 5 & $11.1 \%$ \\
Short Seller & 10 & $9.0 \%$ & -- & -- \\
Market Actors & 8 & $7.2 \%$ & 2 & $4.4 \%$ \\
Strategic Players & 4 & $3.6 \%$ & 1 & $2.2 \%$ \\
External Equity Holders & 23 & $20.7 \%$ & 7 & $15.6 \%$ \\
Employees & 17 & $15.3 \%$ & 4 & $8.9 \%$ \\
Media & 3 & $2.7 \%$ & 1 & $2.2 \%$ \\
Insurance, Plaintiff Law Firms & 81 & $72.9 \%$ & 20 & $44.4 \%$ \\
\hline \multicolumn{2}{r|}{ Total Market Actors } & 111 & 45 & \\
Total Chi-Square Goodness of Fit Test for Distributional Equality: $\chi(8)=28.71$ & pvalue $=0.004$ \\
\hline
\end{tabular}

